\title{
8. The challenges to make women's rights part of Al's DNA
}

This chapter emphasizes the development of AI's work on violence against women in the 2000s. Examing first the international and then the national level, it starts by illustrating how policy on VAW developed within the new framework of human rights provided by AI's mission and how AI integrated VAW into its activities. Chapter 8 demonstrates that unlike its passive role in the 1990s, Al's leadership was the driving force behind policy development on the subject in the 2000 s and behind the implementation of the SVAW campaign. Nevertheless, the SVAW campaign did not succeed in making women's rights an integral part of AI's overall work. Two reasons prevented women's rights from becoming part of AI's DNA: first, the top-down implementation of the SVAW campaign caused female activists and officials who had initiated AI's work on VAW in the 1990s to lose their influence on the organization's work on these issues. Second, activists and officials resisted the SVAW campaign and the adoption of a policy on abortion. The focus on the Swiss and the German sections, however, shows considerable differences with respect to the extent to which AI succeeded in integrating the issue of VAW into its work at the national level. While the Swiss section managed to at least partially integrate VAW into its work, the German section reaped little success in this regard.The German section membership's important opposition to the SVAW campaign and to the adoption of a policy on abortion help explain this divergence. I argue that the German section members' relative closeness to the Church and their comparatively powerful position further account for the difference between the two sections. 


\subsection{The international level}

This chapter first describes the development of AI's policy on VAW (section 8.1.1). It especially highlights the development of AI's first common position on the issue of sexual and reproductive rights (particularly abortion). It continues with an account of the thematic focus and the content of the SVAW campaign, the organization's first long-term thematic global campaign (8.1.2). This section spotlights the campaign's successes and shows that one of its core aims, to mainstream gender throughout the organization, ${ }^{1}$ was not achieved. As the review of the campaign indicated, AI did not succeed in making women's rights part of its DNA.

In addition to providing an in-depth picture of how AI prepared and internally organized the SVAW campaign and of the controversial discussions leading to the adoption of AI's position on abortion, sections 8.1.3 and 8.1.4 also explain AI's failure to make women's rights part of its DNA. Section 8.1.3 demonstrates that the organization's leadership initiated the majority of the ICM decisions concerning AI's work on VAW. I highlight how the management pushed the implementation of the SVAW campaign from the top and describe the establishment of the Machinery for the successful running of the SVAW campaign at the IS. Many of the feminist caucus at the IS, who had pushed the organization to increase its work on issues of VAW in the 1990s, were included in the preparation and, particularly, in the implementation of the campaign as members of the SVAW campaign Machinery. However, the Campaign Team's and the Gender Unit's problematic embedding in the IS and their lack of clear responsibilities and power made it difficult for the women's rights advocates at the IS to effectively implement the campaign. I show that the female activists and officials who had initiated AI's work on VAW in the 1990 s lost their influence on the organization's work on issues of VAW. I argue that this loss of influence was one of the reasons AI did not manage to make women's rights part of its DNA through the SVAW campaign.

$1 \quad$ Gender Mainstreaming refers to a "strategy for making women's as well as men's concerns and experiences an integral dimension of the design, implementation, monitoring and evaluation of policies and programs in all political, economic and societal spheres so that women and men benefit equally and inequality is not perpetuated" (Amnesty International, International Secretariat: Stop VAW Campaign internal strategy, September 2003, p.6). For Al's work on VAW during the SVAW campaign this meant that issues of VAW were not confined to the campaign but were meant to become an integral part of Al's overall work. 
Section 8.1.4 then emphasizes the reactions the SVAW campaign received and the participation in it, and focuses on the debates surrounding the adoption of the ICM decisions on sexual and reproductive rights and abortion. I highlight activists' and officials' resistance to the SVAW campaign and to the adoption of a policy on abortion. The opposition to the campaign was motivated by various factors. Some of the members and officials perceived that the SVAW campaign stood for the broader policy change brought about by the adoption of the mission. They resisted the campaign because they were critical of the adoption of the mission. Other critiques related to the structure and the setting of the campaign, rather than to its content. At the same time, at least part of the opposition was primarily motivated by the issue of the campaign itself. In contrast to the resistance to the campaign, the opposition to the adoption of a policy on abortion, which came from the sections, can more clearly be identified as related to the issue of abortion itself and less to AI's overall policy change. Thus, I argue that several sections' resistance to the adoption of a policy on abortion and the opposition to the campaign are important reasons why AI failed to make women's rights part of its DNA.

\subsubsection{Policy development 2002-2010}

Analyzing ICM decisions allows us to understand AI's policy development in general and that on VAW in particular. Between 2003 and 2010, the ICM took place four times (in 2003, 2005, 2007, and 2009). Each ICM issued between 15 and 40 decisions, ${ }^{2}$ some of which either directly or indirectly concerned AI's work on VAW (highlighted in figure 6).

For the period between 1989 and 2001, I classified the ICM decisions demanding a modification of the mandate as indirectly concerning AI's work on VAW. Because of the adoption of the mission, the ICM no longer made similar decisions in the 2000s. As figure 6 highlights, I classify the ICM decisions that sought a more equal representation of women and men in the organization's membership and leadership as indirectly concerning AI's work on VAW (left side of figure 6). I do so because AI considered the equal representation of women and men within the movement and the adoption of a gender sensitive perspective to be important factors in ensuring the credibility of the SVAW campaign. Evidence shows that the leadership wanted to sensitize the and the 2009 ICM - 15 decisions. 
movement to potential gender inequalities among staff and activists, and it considered the internal commitment to gender equality a (pre)condition for a successful campaign on VAW. An internal document issued prior to the SVAW campaign explains: "We need to establish gender equality at the core of AI's mission and organizational culture to ensure a credible and authentic voice for the issues that the campaign will promote." ${ }^{3}$

The analysis of the ICM reports allows me to identify two types of decisions directly concerning AI's work on VAW: those codifying AI's policy on sexual and reproductive rights, and several others related to women's rights in general (highlighted in the right rectangle of figure 6). With the SVAW campaign, female activists' and officials' demand (reflected in decision 15 of the 1989 ICM, decision 20 of the 1995 ICM, and in decision 32 of the 1997 ICM) to increase the organization's work on women's rights came to fruition. That's why there were no ICM decisions that demanded increases in this work during the period between 2002 and 2010.

Figure 6: Overview of policy developments between 2002 and 2010
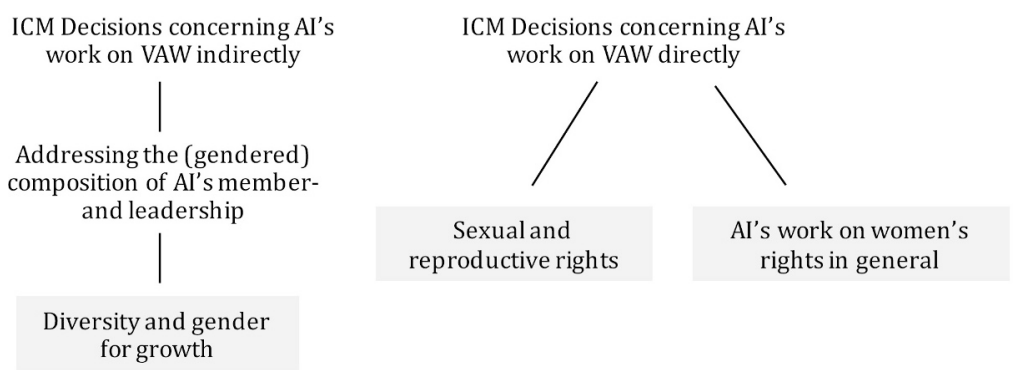

Source: my own, based on the 2003, 2005, 2007, and 2009 ICM reports.

By distinguishing between the ICM decisions directly and indirectly concerning AI's work on VAW, the preceding paragraph has provided a general overview of the development of AI's policy on VAW between 2002 to 2010 . The next section illustrates policy developments by focusing on the content of the ICM decisions adopted between 2002 and 2009. It starts with the description of the decisions indirectly concerning AI's work on VAW before doing the 
same for those directly concerning it. Figure 7 displays all such ICM decisions. I show how gender mainstreaming and the principle of equal representation of men and women became part of Al's policy and demonstrate in detail the internal process leading to the adoption of AI's first position on sexual and reproductive rights, as well as that on abortion.

Figure 7: Detailed policy developments between 2002 and 2010

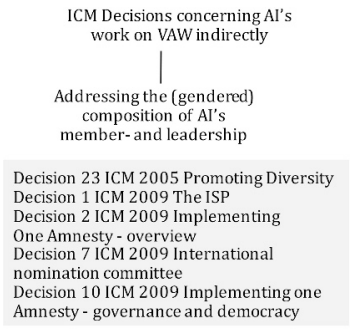

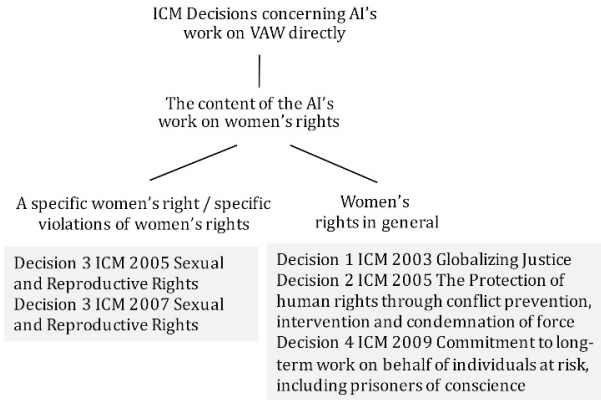

Source: my own, based on the 2003, 2005, 2007, and 2009 ICM reports.

\subsubsection{ICM Decisions indirectly concerning Al's work on VAW}

In the 1990s, AI identified diversity and multiculturalism as issues important for the movement's international growth. ${ }^{4}$ In the 2000 s, AI began to consider gender equality as increasingly relevant to the development of the organization. While equality among its staff and activists had already become an important aspect of the internal SVAW campaign strategy by 2003, AI first integrated the principle of equal representation of women and men into its policy at the 2005 ICM. In decision 5 of the 2005 ICM, the delegates defined "multiculturalism, linguistic plurality, diversity, and equity in both gender and sexual orientation within AI [as] a crucial part of the growth agenda [...]"5 (left side of figure 7). According to this decision, sections were encouraged to

4 Decision 28 of the 1995 ICM that set out the 1996-2001 Integrated Strategic Plan called for a movement-wide implementation of the "standards consistent with Al values, including human resource management strategies covering such issues as multiculturalism and gender equity [...].".

5 Amnesty International, International Secretariat: Report and Decisions of the 27th International Council of Amnesty International, 14th-20th August 2005, p.115. 
develop their own plan for growth and respect gender equality and diversity when deciding on their delegations to international AI meetings.

While AI recognized the importance of a balanced representation of women and men within the organization during the SVAW campaign, the codification of these principles only occurred at the end of the long-term campaign in 2009. At the 2009 ICM, the organization stressed the importance of an equal representation of both genders in all its bodies by making it one of the main objectives of the upcoming Integrated Strategic Plan. At the end of the decade, AI also codified the principle of gender mainstreaming. Figure 7 illustrates that gender equality figured in several decisions of the 2009 ICM as a factor facilitating growth or democracy. The decision thereby codified the principle of diversity and gender equality. Decision 1 of the 2009 ICM stipulated that the 2010 - 2016 strategic plan should enable AI to learn and grow by "[m]aking diversity and gender-mainstreaming a reality," ${ }^{6}$ and defined gender mainstreaming as one of the five pillars of the organization's core work within the ISP "that all AI entities shall undertake."

The International Council also decided to ensure diversity and gender equality in the nominating process for the IEC and other international elected positions (Decision 7). It wanted to make diversity and gender "principles for the movement's democratic governance at all levels" (Decision 10). The IC stated: "AI's governance bodies must be diverse and gender-sensitive." ${ }^{8}$ At the policy level, gender equality thus mostly appeared as a synonym of equal representation of women and men in various hierarchical positions. The analysis of these decisions indicates that gender equality was considered a means to achieving growth and enhancing the movement's democratic governance.

6 Amnesty International, International Secretariat: 29th International Council Meeting Circular 46 ICM Decisions 2009, 16.08.2009, p.3.

7 Amnesty International, International Secretariat: 29th International Council Meeting Circular 46 ICM Decisions 2009, 16.08.2009, p.4.

8 Amnesty International, International Secretariat: 29th International Council Meeting Circular 46 ICM Decisions 2009, 16.08.2009, p.10. 


\subsubsection{Decisions directly concerning Al's work on VAW}

The issue of sexual and reproductive rights first became topical with the launch of the SVAW campaign. While the discussion about AI's work on sexual and reproductive rights had already started around the 2003 ICM, the organization only codified its work at the 2005 and the 2007 ICMs, respectively, and elaborated two respective policies: one on sexual and reproductive rights, and the other on the AI policy on selected aspects of abortion. ${ }^{9}$ As I show in section 8.1.4, finding a common position on sexual and reproductive rights, particularly on abortion, took long, intensive, and controversial discussions. The issue of abortion divided the organization in an unprecedented way and made many long-term activists withdraw from their engagement within AI. The present section highlights the content of the organization's position on sexual and reproductive rights, particularly on the issue of abortion, by focusing on the related ICM decisions. I emphasize the origins of these ICM decisions in section 8.1.3 and describe the related controversial discussions in section 8.1.4.

Following a discussion at the 2003 ICM that did not lead to any decisions, AI organized a movement-wide consultation on sexual and reproductive rights. ${ }^{10}$ Based on it, the International Executive Committee submitted an enabling resolution to the 2005 ICM. The delegates accepted the latter as decision 3 on "Sexual and Reproductive Rights." The content of this decision reveals the sensitivity of the topic. In fact, while it broadly delineates the organization's position on sexual and reproductive rights, it emphasizes the importance of integrating the existing diverging viewpoints on abortion into a policy that should be elaborated in a movement-wide consultation process.

In decision 3, AI affirmed its commitment to defending and promoting sexual and reproductive rights, and averred that the related work should be made in the context of the current ISP. It decided that the IEC would develop a comprehensive statement and a strategy for action on sexual and reproductive rights. A future policy would support the right of access to information about sexual and reproductive health as well as the right of access to sexual and reproductive health services, including contraception. In addition, decision 3 also specified that a "consultation, education, and awareness-raising

Amnesty International, International Secretariat: Amnesty International policy on selected aspects of abortion, 20.04.2007.

10 Amnesty International, International Secretariat: Amnesty International policy on selected aspects of abortion, 20.04.2007, p.15. 
process"11 should be initiated in order to enable the organization to make an informed decision about its position on abortion.

For the first time, AI considered abortion to be closely related to women's subordinated position in society, recognizing "that the need for abortion in a large number of cases is a consequence of violence against women, a lack of empowerment of women as well as of a lack of access to education and health services like contraception." ${ }^{12}$ At the same time, the content of the decision reveals the disagreement on the question of whether AI should defend a woman's right to abortion. It specified that:

"the [consultation, education, and awareness-raising] process should enable Al to take an informed decision as to the organization's position - should it choose to do so - on the question of whether a woman's right to physical and mental integrity includes her right to terminate her pregnancy, subject to reasonable limitations, and of whether abortion should therefore be legal, safe and accessible to all women." ${ }^{13}$

The IEC was given the chance to "fast-track' decision-making"14 on three aspects of abortion, namely the decriminalization of abortion, access "to quality services for the management of complications arising from abortion," and "legal, safe and accessible abortion in cases of rape, sexual assault, incest, and risk to a woman's life." 15 Later, these three aspects formed the core of the AI policy on selected aspects of abortion adopted in $2007 .{ }^{16}$ All other possible AI positions on the issue of abortion were postponed for discussion at the 2007 ICM. $^{17}$

11 Amnesty International, International Secretariat: Report and Decisions of the 27th International Council of Amnesty International, 2006, p.104.

12 Amnesty International, International Secretariat: Report and Decisions of the 27th International Council of Amnesty International, 2006, p.103.

13 Amnesty International, International Secretariat: Report and Decisions of the 27th International Council of Amnesty International, 2006, p.104.

14 Amnesty International, International Secretariat: Amnesty International policy on selected aspects of abortion, 20.04.2007, p.2.

15 Amnesty International, International Secretariat: Report and Decisions of the 27th International Council of Amnesty International, 2006, p.104.

16 Amnesty International, International Secretariat: Amnesty International policy on selected aspects of abortion, 20.04.2007.

17 Amnesty International, International Secretariat: Report and Decisions of the 27th International Council of Amnesty International, 2006, p.104. 
The principles of AI's work on sexual and reproductive rights, which also served as the frame of a future policy on abortion, was subject to a policy paper in October 2006. ${ }^{18}$ In the document, the IEC stated that sexual and reproductive rights were "central to the realization of every individual's human rights" and stressed AI's belief "that all persons must be enabled to enjoy their sexual and reproductive rights free of coercion, discrimination and violence."19 Further, in the "Statement Summarizing Al's Current Policy on Sexual and Reproductive Rights," sexual and reproductive rights were framed as an issue of civil and political rights: "The realization of sexual and reproductive rights requires respect for rights relating to physical and mental integrity, such as the right to life, [...], ${ }^{20}$ as well as an issue of economic, social, and cultural rights: "The realization of sexual and reproductive rights requires also respect for economic, social and cultural rights, such as the right to education and the right to the highest attainable standard of health [...]." ${ }^{21}$ In the same document, AI further affirmed its commitment to defending and promoting these rights in the context of its mission, its core values, and its strategic goal. Finally, AI called upon the responsibility of the state to respect, protect, and fulfill the sexual and reproductive rights of every person, and upon the responsibility of other societal actors, such as corporate actors or health professionals, to do so, as well. ${ }^{22}$

After a movement-wide consultation process, AI adopted its policy on selected aspects of abortion ${ }^{23}$ in April 2007. Based on the three aspects of abortion that were considered capable of drawing a consensus within the movement at the 2005 ICM, the policy called for the decriminalization of abortion but recognized "the right of states to impose reasonable limitations on access to

Amnesty International, International Secretariat: Statement Summarizing Al's current policy on Sexual and Reproductive Rights, 12.10.2006.

19 Amnesty International, International Secretariat: Statement Summarizing Al's current policy on Sexual and Reproductive Rights, 12.10.2006, p.2. Amnesty International, International Secretariat: Statement Summarizing Al's current policy on Sexual and Reproductive Rights, 12.10.2006, p.3.

21 Amnesty International, International Secretariat: Statement Summarizing Al's current policy on Sexual and Reproductive Rights, 12.10.2006, p.3.

Amnesty International, International Secretariat: Statement Summarizing Al's current policy on Sexual and Reproductive Rights, 12.10.2006.

23 Amnesty International, International Secretariat: Amnesty International policy on selected aspects of abortion, 20.04.2007. 
abortion services." 24 It called for access to quality health services in cases of complications arising from abortions, and it requested that states provide access to legal, safe, and accessible abortions "in the case of an unwanted pregnancy as a result of rape, sexual assault or incest, or if the pregnancy poses a risk to the life or grave risk to the health of the woman." 25 It further called for sexual and reproductive health services for women and men, recognizing their importance for the prevention of unwanted pregnancies and abortions. ${ }^{26}$ The policy thus enabled AI to help "those women who wish to end unwanted pregnancies resulting from sexual violence, [...] to support women who seek treatment for complications arising from abortion," and "to oppose imprisonment or other criminal penalties for abortion." 27

That same autumn, the ICM delegates accepted decision 3 at the 2007 ICM. By adopting this decision, the organization codified the previously adopted policy documents on sexual and reproductive rights and abortion. In fact, decision 3 of the 2007 ICM stipulated that:

"the recently adopted policy on: decriminalization of abortion; access to quality services for the management of complications arising from abortion; legal, safe and accessible abortion in cases of rape, sexual assault, incest, risk to the life or grave risk to the health of the woman enables the organization to tackle the grave violations of women's human rights that fall within its mission and its SVAW campaign strategy."28

At the same time, AI confirmed the importance of strengthening preventive work in order to avoid unwanted pregnancies and the recourse to abortions, and it recognized that the work on these issues needed to be "discussed across the movement before AI can make an informed decision about further policy development in relation to other aspects of sexual and reproductive rights not covered by existing policies." 29

24 Amnesty International, International Secretariat: Amnesty International policy on selected aspects of abortion, 20.04.2007, p.3.

25 Amnesty International, International Secretariat: Amnesty International policy on selected aspects of abortion, 20.04.2007, p.3.

26 Amnesty International, International Secretariat: Amnesty International policy on selected aspects of abortion, 20.04.2007.

27 Amnesty International, International Secretariat: Amnesty International policy on selected aspects of abortion, 20.04.2007, p.3.

28 Amnesty International: 28th international Council Meeting, 2007, p.67.

29 Amnesty International: 28th international Council Meeting, 2007, p.87. 
Consequently, after long and intensive movement-wide consultations and debates, the organization finally reached a consensus and codified its policy on sexual and reproductive rights and abortion in 2007. Therein, AI considered sexual and reproductive rights as part of every person's human rights, and it framed these rights as civil and political rights and as economic, social, and cultural rights. The decriminalization of abortion and legal, safe, and accessible abortion, if the unwanted pregnancy is a result of any form of VAW or if the pregnancy endangers the life of the pregnant woman, formed the core principles of AI's position on abortion. AI also agreed on the importance of providing sexual and reproductive health services to women and men, recognizing its importance for the prevention of unwanted pregnancies and abortions. While stressing each individual's right to freely decide on his or her sexuality and reproductive life, AI did not stand for a woman's right to freely choose if she desired to terminate her pregnancy or not. Thus, while AI defended the sexual and reproductive rights of every individual, it adopted a more restrictive position towards abortion, limiting the right to abortion to threatened women, while demanding that the state decriminalize the practice. As I detail later, AI's policy on selected aspects of abortion (widely criticized by women's rights organizations) was a compromise between those within AI who were calling for the right to abort and others who espoused the view that AI should not take a position on the issue.

In addition to the controversial policy-making on sexual and reproductive rights, the organization made three ICM decisions (decision 1 of the 2003 ICM, decision 2 of the 2005 ICM, and decision 4 of the 2009 ICM) concerning other aspects of its work on VAW. The following paragraph briefly presents the content of these decisions.

In decision 1 of the 2003 ICM on "globalizing justice," the delegates decided to make women's rights and VAW an integral part of AI's upcoming 2004 to 2010 ISP. In fact, one of the fifteen goals of the ISP stated that AI should emphasize the strengthening of "the protection of women and girls in international, regional and national law" and that AI should demand "accountability of states regarding respect, protection and fulfillment of rights for women and girls" and "accountability of non-state actors regarding the rights of women and girls." Further, the same goal stipulated that AI should "work in alliance with the women's movement to increase awareness and human rights education towards the eradication of violence against women and 
girls." ${ }^{30}$ Reflecting the objectives of the internal SVAW campaign, the same goal also highlighted the importance of promoting women's rights inside AI and the commitment of its membership and staff to these rights. In accordance to one of the main objectives of the public SVAW campaign, decision 2 of the 2005 ICM resolved to strengthen the movement's work on women in conflicts by emphasizing, among other things, "the ways in which military actions disproportionately affect women,"31 and by searching for solutions to this disparity. Furthermore, at the 2009 ICM, the delegates decided to ameliorate AI's long-term work on behalf of individuals at risk by committing to an equal representation of women and men in its cases of prisoners of conscience (Decision 42009 ICM).

Summing up, AI's policy on VAW mainly developed in two domains in the 2000s. First, at the end of the decade, AI codified gender equality as an important principle of internal governance and growth, and emphasized the importance of integrating women's rights in all areas of its work by codifying the principle of gender mainstreaming. Second, for the first time, AI discussed and decided upon a common position on sexual and reproductive rights and adopted the AI policy on selected aspects of abortion. ${ }^{32}$

\subsubsection{Policy Implementation - Focus and content of the SVAW campaign}

In the 2000s, most of AI's activities on VAW fell within the SVAW campaign. Before describing the content of AI's first global thematic long-term campaign, it is worth it to briefly highlight the institutional context of its implementation. This would allow us to appreciate the challenge that the SVAW campaign represented for the organization and would improve our understanding of the difficulties AI faced in its attempts to integrate VAW into its work. As I have highlighted before, at the turn of the millennium, AI radically changed its approach to human rights by adopting a mission that encompassed all human rights, including economic, social, and cultural rights. As

30 Amnesty International, International Secretariat: Report and Decisions of the 25th International Council of Amnesty International, 2004, p.97.

31 Amnesty International, International Secretariat: Report and Decisions of the 27th International Council of Amnesty International, 2006, p.102.

32 Amnesty International, International Secretariat: Amnesty International policy on selected aspects of abortion, 20.04.2007. 
a consequence, $\mathrm{AI}$ also changed its working methods. For example, it abandoned the WOOC rule and undertook a shift away from campaigning centered around the country and the individual and toward thematic campaigning. Furthermore, collaboration with external actors, such as other human rights or women's rights organizations or experts, became increasingly important during this period, as AI lacked internal expertise in working in the domain of social, economic, and cultural rights and in framing the related work on VAW. As Wallace and Baños (2010) highlight, these modifications signified "a real break with the past"33 and the SVAW campaign was the "flagship" of these changes. ${ }^{34}$ Observing its potential, the IEC explained: "We look forward [...] to the human rights revolution we hope [the SVAW campaign] will inspire!!"35 Relatedly, as an extract of Irene Khan's speech to the delegates at the 2003 ICM illustrates, AI's leadership attached great expectations to the SVAW campaign:

"We stand together, as a movement, at the threshold of an extraordinary opportunity which is the SVAW campaign. I feel, hear and witness the tremendous power of this coming campaign to change inside and outside Al. Through this campaign we will ask you to turn to your own communities and to seek out and act against the violence [...]. We will bring human rights home to every woman. [...]"36

The IS Campaign Team saw the SVAW campaign as a transitional undertaking "in which we are moving from our 'old' style campaigning towards new ways of working, ${ }^{37}$ in which campaigning began to determine research. The increasing importance of thematic campaigning challenged the prominence of AI's researchers at the IS, who had traditionally benefited from a highly valued status. It is therefore not surprising that this group of officials at the IS voiced the most active resistance to the campaign.

AI implemented the campaign in two phases. The first took place between 2003 and 2005 and the second between 2007 and 2010. Initially planned for

33 Wallace and Baños Smith 2010b, p.9.

34 Wallace and Baños Smith 2010b, p.9.

35 Amnesty International, International Executive Committee: IEC Information Bulletin 48, 02.03.2004, p.5. Amnesty International, International Secretariat: Report and Decisions of the 26th International Council of Amnesty International, 2003, p.14.

37 Stop VAW campaign team: STOP VAW Campaign Progress update 4, 12.2003 , p.9. 
two years, the SVAW campaign developed into a global campaign for the duration of the ISP when the IEC approved this change in January $2004 .{ }^{38}$ Without going into detail, the following paragraphs provide an overview of the campaign's thematic content during its two phases. ${ }^{39}$ Then, section 8.1.3 highlights how AI pushed for the implementation of the campaign from the top down.

AI launched the SVAW campaign with an internal campaign at the 2003 ICM because, in the words of the IEC Chair: "We are launching an internal SVAW campaign at this ICM because frankly we need to walk the walk before we can talk the talk on this campaign." ${ }^{40}$ As Irene Khan pointed out, the staff's and activists' commitment to gender equality was pivotal for the public credibility of AI's work on VAW. It also was an important condition for the establishment of an effective partnership with the women's movement a necessity for the SVAW campaign' success. ${ }^{41}$

The so-called Gender Action Plan (GAP) ${ }^{42}$ formed the core of the internal campaign. The plan served as an internal strategy to coherently connecting the public campaign message and the organization's internal functioning. In the GAP, AI emphasized the need to become a "gender equitable organization"43 and stressed the necessity to "ensure that gender is mainstreamed throughout the organization and not confined solely to the VAW Campaign." 44 In fact, "[o]ne of the key aims of the SVAW campaign was to mainstream gender throughout Amnesty International's work - to bring it into the DNA of the organization." 45 The GAP sought to do this with concrete measures, such as gender-awareness training or gender-sensitive tools and guidelines. ${ }^{46}$ Further,

\footnotetext{
38 Amnesty International, International Executive Committee: IEC Information Bulletin 48, 02.03.2004.

39 For more details on the campaign, consult: Wallace and Baños Smith $2010 \mathrm{~b}$.

40 Amnesty International, International Secretariat: Report and Decisions of the 26th International Council of Amnesty International, 2003, p.9.

41 Khan 2003, p.9.

42 Amnesty International, International Secretariat: Stop VAW Campaign internal strategy, September 2003.

43 Amnesty International, International Secretariat: Stop VAW Campaign internal strategy, September 2003, p.7.

44 Amnesty International, International Secretariat: Stop VAW Campaign internal strategy, September 2003, p.7.

45 Wallace and Baños Smith 2010b, p.141.

46 Miller 2006, p.28.
} 
internal gender audits at various level of the organization would ensure that gender was integrated "into AI's way of working internally." ${ }^{27}$ Similarly, staff members were supposed to integrate a gender perspective into their work and to do research on issues of VAW within their specific regional responsibilities. Sections were also asked to subsequently develop and implement their own GAPs based on the overall GAP. ${ }^{48}$

Following the internal launch of the campaign, AI launched its public campaign on the $8^{\text {th }}$ of March 2004. Its first phase essentially concentrated on two topics: "VAW in armed conflicts" and "Domestic violence" (figure 8). In addition, AI continued to implement the GAP.

Figure 8: First phase of the SVAW campaign, 2003-2005

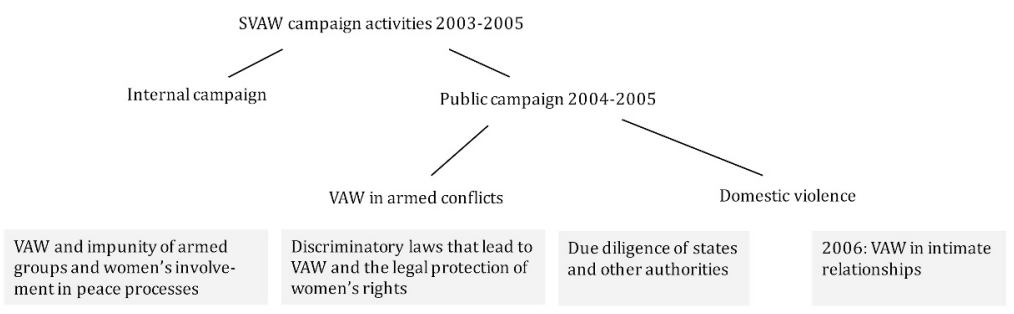

Source: my own

"VAW in armed conflicts" and "Domestic violence" were operationalized in three campaign projects (highlighted in the three gray rectangles of figure 8) which reflected the importance of the concept of "'due diligence' as the main analytical tool of the SVAW campaign." ${ }^{49}$ One project focused on armed groups' impunity for acts of violence against women and on women's involvement in peace processes. Another project concentrated on discriminatory laws that lead to violence against women and the legal protection of women's rights. A third project emphasized the responsibility of "states, national, local and municipal authorities to respect, protect, and fulfill women's rights to be free from violence." 50

\footnotetext{
47 Wallace and Baños Smith 2010b, p.96.

48 The implementation of the GAPs at national level is discussed in chapter 9.2.

49 Ganzfried: Correction of citation A.W., 22.08.2018, p.1.

50 Amnesty International, International Secretariat: Stop Violence Against Women 20042010 Campaign projects for 2004-2006, July 2004, p.7.
} 
In the frame of the public campaign, AI produced many materials defining its approach to issues of VAW. For example, under the campaign, AI defined the persecution of adultery or "zina," considered a crime under sharia law, as a human rights violation. Further, legal officers developed due diligence standards that determined how the movement should deal with the issue of violence in the family and prepared standards on the work on VAW in armed conflicts, both of which were considered important contributions to holding governments and other actors accountable for violence against women. ${ }^{51}$ The IS prepared a huge number of actions for each of the projects, which the sections subsequently implemented. For example, sections worked towards the CEDAW's ratification and implementation by lobbying their respective governments, or they collaborated with other NGOs to pressure governments to abolish laws that discriminated against women. ${ }^{52}$ Lobbying for the implementation of the UN resolution 1325 was one of the activities within the second project. 53

Before launching the second phase of the campaign, AI focused on the issue of violence against women in intimate relationships (highlighted in the white rectangle on the right side of figure 8). Thereby, AI addressed the gap between law and implementation and stressed the importance of women's empowerment for a life without violence. ${ }^{54}$

During the second phase, AI continued with the implementation of the Gender Action Plan (GAP) within the internal campaign (highlighted on the left side of figure 9), stating: "We must be confident that the values we advocate externally are those which we observe within our internal organizational culture." 55 The GAP remained the relevant policy document for the achievement of the internal campaign goal: "change ourselves to change the world." 56 At the same time, even though the campaign strategy of the second phase stated that AI wanted "to build on the achievements and use the knowledge and ex-

\footnotetext{
51 Ganzfried: Correction of citations A.W., 24.08.2018.

52 Amnesty International, International Secretariat: Stop Violence Against Women 20042010 Campaign projects for 2004-2006, July 2004.

53 Amnesty International, International Secretariat: Stop Violence Against Women 20042010 Campaign projects for 2004-2006, July 2004.

54 Amnesty International, International Secretariat: Phase IV - VAW in the family action circular: "VAW in intimate relationships", 02.01.2006.

55 SVAW Team (IS): SVAW campaign strategy: “Make rights real!”, October 2006, p.28.

56 SVAW Team (IS): SVAW campaign strategy: "Make rights real!", October 2006, p.28.
} 
perience gained in the first phase of the campaign, ${ }^{, 57}$ issues of VAW were only integrated into one of three main campaign goals of the second phase. In fact, AI continued its work on VAW in the frame of the newly defined goal of "Human rights concerns." However, it used the second campaign phase to address and resolve the general problem of member stagnation, which it had been facing since the 2000s. Thus, AI defined "Human rights concerns," "Growth of activism globally on VAW," and "Growth of AI through the SVAW Campaign" as the three objectives of the second phase (highlighted in figure 9)..$^{58}$

Figure 9: Activities in the second phase of the SVAW campaign, 2007-2010

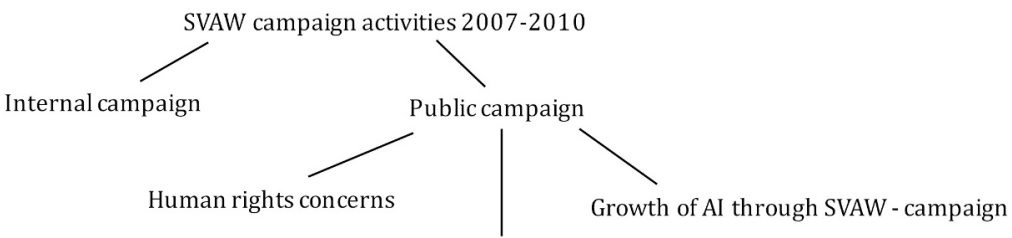

Growth of activism globally on VAW

Source: my own

In the frame of the objective "Human rights concerns," AI campaigned for several initiatives, such as "Safe schools for girls," "Safe work places for women," 59 and services for women survivors of sexual violence, as defined in its newly adopted policy on abortion. ${ }^{60}$ At the same time, under the campaign goals "Growth of activism globally on VAW" and "Growth of AI through the SVAW Campaign," AI called for increasing activism in regions where it traditionally had few members (such as the Middle East or Africa) and specifically sought to reach out to young people and women. Not only did AI modify the focus of the campaign; it also lessened the campaign's intensity during the second phase of the campaign. Wallace and Baños (2010) explain that, compared to the first phase: "much less work was undertaken under the second strategy by researchers and [sections]. ${ }^{61}$ As an example, the first phase

\footnotetext{
57 SVAW Team (IS): SVAW campaign strategy: “Make rights real!”, October 2006, p.4.

58 These areas were developed in consultations with all sections and structures.

59 SVAW Team (IS): SVAW campaign strategy: "Make rights real!", October 2006.

60 SVAW Team (IS): SVAW campaign strategy: “Make rights real!", October 2006, p.9.

61 Wallace and Baños Smith 2010b, p.139.
} 
saw the publication of an average of 60 documents per year; this number decreased to 14.2 publications per year during the second phase of the campaign. ${ }^{62}$

Lacking a clear exit strategy, the SVAW campaign ended with a final communication advisory in March 2010, which indicated how to take various aspects of the SVAW campaign work forward. Yet, it did not specify how existing activities and relationships with women's rights NGOs should be concluded or continued. ${ }^{63}$ As I highlight later, considerable uncertainty surrounded the question of how work on issues of VAW should continue after the SVAW campaign, and the professional future of those working for the campaign within the IS (in the Campaign Team) and within sections remained unclear.

In a nutshell, the internal campaign sought to mainstream gender throughout the organization. VAW in the private sphere - namely "Domestic violence" and "Violence in intimate relationships" - became the main topics of the first phase of the public campaign. Meanwhile, growing the movement through the campaign became the central topic in the latter's second phase.

Since the majority of AI's activities on issues of VAW in the 2000 s were organized under the umbrella of the SVAW campaign, the success of the latter can inform us about the extent to which AI succeeded in integrating VAW into its work. The campaign's 2006 mid-term evaluation and its final review provide an in-depth picture of its successes and failures. ${ }^{64}$ Because the present research project does not seek to assess the campaign and is instead interested in understanding the causes behind the identified failures, I only briefly recapitulate the evaluation's conclusions. The SVAW campaign allowed the movement to embrace economic, social, and cultural rights, and helped women's rights become better recognized as a part of the organization's work. ${ }^{65}$ The production of wide-ranging research on diverse topics re-

62 Whereas the IS published 38 campaign reports in two years (between 2004 and 2005), it produced 26 reports during the four years of the second phase of the campaign (between 2006 and 2010) (Wallace and Baños Smith 2010b, p.149). Also counting the internal documents, 120 documents (public and internal) concerning the SVAW - campaign were produced by the IS in the first phase, and 71 papers were released in the four years of the second phase. Based on information from the AIDAN Search base on Al Intranet. Using the following keywords: AI Class: ACT; Sub-Class: 77; Year: 2004-2010 (Last consultation 17.10.2014).

63 Wallace and Baños Smith 2010b, p.179.

64 Miller 2006; Wallace and Baños Smith 2010b.

65 Wallace and Baños Smith 2010b, p.176. 
lated to women's rights was an important achievement. Specifically, the research and campaigning realized within the Northern sections had a real impact as a consequence of the cancellation of the WOOC rule. ${ }^{66}$ Further, the recognition of collaborating in the domain of VAW led to many fruitful partnerships with local NGO's working on women's rights, which in turn helped AI to act locally against violence against women. ${ }^{67}$

The mid-term review of the campaign also revealed that "the SVAW campaign ha[d] given greater legitimacy to research on VAW" realized by country researchers "and that the Campaign Team (and the Gender Unit) ha[d] facilitated this kind of work through providing resources and research backstopping. ${ }^{68}$ According to Miller (2006), a positive outcome of the first two years of the campaign was its contribution to a greater awareness of the relevance of gender equality and women's rights to the work of AI among the staff at the IS. ${ }^{69}$ Additionally, AI also developed some important policy positions, such as the policy on the restricted aspects of abortion that called on governments to decriminalize abortion, or its position on states' responsibility for the prevention of violence by non-state actors (due diligence). ${ }^{70}$ While the SVAW campaign led to a rise in the active memberships of some sections, others developed new partnerships with local organizations or introduced innovative campaign methods. ${ }^{71}$ On a broader scale, the campaign contributed to VAW becoming universally perceived as a human rights issue. ${ }^{72}$ Even though it is difficult to assess the global impact of the campaign, good AI lobbying and campaigning led i.a.

"to changes in attitudes (for example, around rape in the Nordic countries), policy (for example, the provision of shelters for women in municipalities in Sweden), awareness (lobbying work in several countries and strong membership engagement), partnerships (for example, through the GBV

\footnotetext{
66 Wallace and Baños Smith 2010b, p.176.

67 Amnesty International, International Secretariat: SVAW Campaign 2006-2010 Draft Strategy for Consultation, 21.12.2005, p.8.

68 Miller 2006, p.28.

69 Miller 2006, p.28.

70 Wallace and Baños Smith 2010b.

71 Wallace and Baños Smith 2010b, p.177.

72 Amnesty International, International Secretariat: SVAW Campaign 2006-2010 Draft Strategy for Consultation, 21.12.2005, p.3.
} 
and EVAW networks in Ireland and the UK...), and improved legal rights for women experiencing violence." ${ }^{73}$

In addition to these important achievements, the final review concluded that the campaign had failed in one important aspect. Namely, it did not succeed in making women's rights part of the organization's DNA. ${ }^{74}$ The most important evidence of this failure manifests in the GAP's faltering and in the Demand Dignity campaign's nonexistent "gender analysis or aims around women's rights." 75 It is thus worth asking why AI did not succeed in sustainably integrating women's rights into its work through the SVAW campaign? I first focus on AI's policy-making style and on the campaign's implementation (section 8.1.3). I then examine the reaction the SVAW campaign elicited, the participation in it, and the debates accompanying the adoption of the ICM decisions on sexual and reproductive rights (section 8.1.4). I do so to show that the main reasons for this failure had to do with the fact that the female activists and officials who had initiated AI's work on VAW in the 1990s lost their influence on the organization's VAW work during the SVAW campaign and with the resistance that the campaign and the adoption of a policy on abortion faced from activists and officials alike.

\subsubsection{Pushing work on the issue of VAW from the top down}

This section demonstrates that, in contrast to the 1990s, AI pushed the work on VAW from the top down. The section starts by illustrating the IEC's pivotal role in the adoption of the ICM decisions directly and indirectly concerning AI's work on VAW. Then, the section focuses on the SVAW campaign preparation period and examines the management's leading role in it. I later provide details on the SVAW campaign Machinery and highlight the role the different components of the machinery played in the implementation of the campaign. I specifically focus on the Campaign Team and the Gender Unit and highlight how their problematic embeddedness into the IS and their lack of clear responsibilities and power hampered this implementation. In doing so, I show that the top-down implementation of the SVAW campaign meant that the female activists and officials who had initiated AI's work on VAW in the 1990s lost their influence on the organization's work in this domain.

\footnotetext{
73 Wallace and Baños Smith 2010b, p.177.

74 Wallace and Baños Smith 2010a, p.16.

75 Wallace and Baños Smith 2010a, p.16.
} 


\subsubsection{Policy development initiated by the IEC}

This paragraph highlights the important role that the IEC and the SG played in pushing policy development on VAW further. The classification of the ICM decisions into two groups based on their origin from a resolution submitted by either a section or several sections (illustrated on the left in figure 10) or by the IEC (illustrated on the right in figure 10) shows that the IEC initiated all but one ICM decision, whether directly (underlined in figure 10) or indirectly concerning the work on violence against women.

Figure 10: ICM decisions and their initiators, 2003-2009

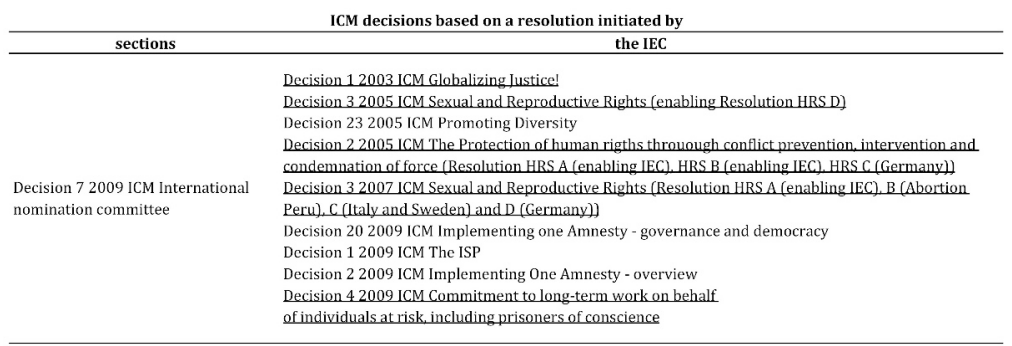

Source: my own, based on the 2003, 2005, 2007, and 2009 ICM reports*

"Decision 2 (2005 ICM) is classified as coming from the IEC because two of the original resolutions were enabling resolutions. Decision 3 (2007 ICM) is classified as coming from the IEC because it followed decision 3 of the 2005 ICM, which originated from an enabling resolution.

The classification in figure 10 highlights the important role the IEC played in shaping AI's policy development concerning the organization's work on VAW in the 2000s. Given the overlap between the IEC and the SG highlighted in chapter 6 , and in light of the fact that a huge majority of the ICM decisions originated from enabling resolutions, the classification also indicates the existence of a top-down process of policy development. Thus, while the decisions calling for an increase in AI's work on women's rights in the 1990 s had been initiated by female activists and officials organized in the IWN, evidence indicates that female activists were no longer the driving forces behind the development of AI's policy on VAW in the 2000 s. 


\subsubsection{Getting ready for the SVAW campaign}

The following paragraphs demonstrate the management's leading role in preparing the SVAW campaign and the IWN activists' and officials' shrinking importance in the planning of the top-down endeavor.

As a "flag-ship" for the changes in focus and working methods brought about by the adoption of the mission, the SVAW campaign was conceived as a top-down endeavor from its beginning. This meant that its preparation and implementation were steered from within the IS. Consequently, the SG and her deputy played a leading role in the campaign's preparation. Evidence further shows that, in addition to this, the SG deputy also pushed AI's work on issues of VAW in this period. According to one interviewee: "[Irene Khan] pushed it quite hard and the second person, who was Kate Gilmore, extraordinary, I mean she was a proper feminist. ${ }^{.76}$ Another considered Kate Gilmore the key figure stating: "the arrival of somebody like Kate Gilmore to the Secretariat. [...] So, she came in and she just, you know, 'we must do gender. Again, we just look like a dinosaur; we need to get some serious gender analysis." 77 Similarly, another interviewee qualified Kate Gilmore as "a very powerful figure pushing for women's rights. ${ }^{78}$

The importance of the IS, the SG and her deputy for AI's work on issues of VAW was reinforced by the dissolution of the IWN in $2002 .{ }^{79}$ The fact that the IWN's fourth and last meeting held in London in April 2002 was organized by the IS (unlike previous gatherings) already indicates that the issue of VAW was pushed increasingly from the top down. This top-down approach and the leading roles that SG Irene Khan and her Deputy Kate Gilmore played in preparing the SVAW campaign were reflected in, among other things, three campaign preparation meetings in May 2002, October 2002, and July 2003. Organized prior to the launch of the internal campaign, these gatherings sought to create a broad commitment to the campaign among activists and officials. They were informed by the need to include the women's rights movement, deemed essential for the success of the campaign. By inviting Charlotte Bunch of the Center for Women's Global Leadership and Roxanna Carillo from

76 Ganzfried: Interview with A.X., 25.06.2012.

77 Ganzfried: Interview with B.R., 25.06.2012.

78 Ganzfried: Interview with B.R., 25.06.2012.

79 Despite the fact that no archive material puts the dissolution of the IWN in black and white, the fact that I could not find any minutes of IWN meetings after 2002 indicates that the network ceased to exist. 
the UN Development Fund For Women (UNIFEM), two important figures in the women's rights movement, the first meeting, organized exclusively for the IS staff, sought to inform "the IS thinking and planning to deliver the forthcoming campaign on VAW." 80 There, Roxanna Carillo emphasized the necessity to work with the women's movement by stating that AI "had to overcome the 'general perception from the women's movement about AI ... Always going solo ... which could hamper AI's credibility as a voice for women's human rights." 81

After a movement-wide consultation, Irene Khan convened a second campaign-preparation meeting with sections and IS representatives and again invited several high-profile figures of the women's rights movement ${ }^{82}$ with the goal of discussing and deciding upon the campaign's focus. There, the participants chose "domestic violence" and "VAW in armed conflicts" as the primary themes of the campaign, and approved the twofold campaign strategy (an internal launch followed by a public campaign starting around 8 March 2004). Therefore, the campaign's focus can be considered the fruit of a movementwide consultation and of the inclusion of voices from the women's rights movement. Indeed, it was the latter who suggested making "domestic violence" the principal theme of the campaign. ${ }^{83}$

At the third consultation meeting in Oxford in July 2003, the SG invited IS staff, officials and activists from sections with the aim of building a movement-wide engagement in the preparation of the VAW campaign and of initiating the internal transformative processes necessary for ensuring the effectiveness of the campaign. Once again, an important number of prominent international women's rights and "gender and organizational change" experts ${ }^{84}$

80 Amnesty International, International Secretariat: IS Staff Forum on Violence Aganist Women Campaign 9 May 2002, 12.05.2002, p.1.

81 Hopgood 2006, p.153.

82 Roxanna Carrillo (Unifem), Doo Aphane (Women and Law in Southern Africa), Shamima Ali, Fiji (Women's Crisis Centre), Indai Sajor (International Criminal Justice Institute), Asma Khadeer (Sisterhood is Clobal Institute in Jordan) (Amnesty International, International Secretariat: Report of the Violence Aganist Women Campaign Consultation Forum, 14.11.2002).

83 Amnesty International, International Secretariat: Courrier électronique hebdomadaire 40/02 à l'attention des coordonnatuers Campagnes, 23.10.2002

84 Among the invited experts were: Radhika Coomaraswamy (former UN Special Rapporteur on VAW), Zaitun Mohammed Kassim (independent consultant and member of Sisters in Islam Malaysis), Agnes Callamard (Executive Director of the Geneva-based 
were invited to help AI in assessing its organizational culture and identifying the key internal challenges that AI needed to address, if it was to carry out a credible and effective campaign on VAW. ${ }^{85}$ At the Oxford meeting, the SG stressed the importance of the internal campaign by emphasizing the consistency between AI's internal culture and its public statements: "An internal strategy to facilitate a movement-wide understanding of gender-based violence and its root causes and human rights consequences is inevitable if we are to guarantee this long-term commitment." ${ }^{86}$ It became evident that "without exposing itself to the gender lens, Amnesty could have no hope of political authority with the women's movement." ${ }^{87}$ At this last preparatory consultation meeting, the participants decided to make "change ourselves to change the world" 88 the slogan of the internal campaign, and labeled the public campaign "Stop Violence Against Women." 89

\subsubsection{The SVAW campaign Machinery}

AI established new organizational entities, some of which were at the IS, to ensure the smooth running of the campaign. Making use of the name one of my interviewees mentioned, I label these bodies the SVAW campaign Machinery. This section describes the role and the functioning of the Machinery in detail. As the left side of figure 11 highlights, it was made up of the Campaign Team and the Gender Unit at the IS. The creation of these two new units required substantial financial resources, as it entailed the creation of new posts. It is therefore not astonishing that these entities were key to the running of the campaign.

Further, the Campaign Steering Committee and the SVAW network also formed part of the SVAW campaign Machinery. These were decentralized entities composed of IS and section staff, namely the section's campaign coordinators, who were specifically appointed for the preparation and the

Humanitarian Accountability Project International), Nira Yuval Davis (Prof. in Cender, Sexualities and Ethic Studies at University of East London).

Khan: Letter from the secretary general Irene Khan to sections, 16.09.2003; Amnesty International, International Secretariat: VAW Campaign progress update 28 July 2003 , 28.07.2003.

86 Amnesty International, International Secretariat: The VAW campaign An Agenda for Cender Equity The proposed framework for the "internal strategy", 01.07.2003, p.1.

87 Hopgood 2006, p.153.

88 Khan: Letter form Irene Khan to sections, 01.04.2004.

89 Hopgood 2006, p.237. 
implementation of the campaign at the sectional level. In the present section, I provide details on the Campaign Team and the Gender Unit. I then highlight how their embeddedness in the headquarters and their lack of clear responsibilities and power hampered the implementation of the campaign. In doing so, I also show that the female activists and officials who had initiated AI's work on VAW in the 1990s lost their influence on the organization's work on issues of VAW because of the top-down nature of the campaign. This loss of influence can in turn be seen as one of the reasons why the SVAW campaign did not succeed in making women's rights part of AI's DNA. Later, I focus on the decentralized entities in the SVAW campaign Machinery - the SVAW network and the Campaign Steering Committee. ${ }^{90}$ I provide further details on how AI organized the campaign's implementation at the national level in the upcoming sections on the Swiss and the German sections (section 8.2).

Figure 11: The SVAW campaign Machinery

\section{Centralized at the IS}

Campaign Team Gender Unit

\section{Decentralized}

Campaign Steering SVAWnetwork Committee

Source: own

The Campaign Team was responsible for promoting the movement's campaign and coordinating the campaign. ${ }^{91}$ It was in charge of drafting the campaign strategies, heading the communication about the campaign, and providing the regional research teams at the IS with advice and support throughout the duration of the entire campaign. ${ }^{92}$ The team thus had to closely col-

90 While many archival documents contained information about the Campaign Team and relatively many interviewees mentioned the Campaign Team and the Gender Unit, information on the SVAW network and on the Campaign Steering Committee was scarce. Consequently, the following paragraphs on the Campaign Team and the Cender Unit dig deeper than the passages on the Campaign Steering Committee and the SVAW network. This difference may be interpreted as reflecting the pivotal role the Campaign Team and the Gender Unit played in the implementation of the SVAW campaign, in contrast to the two decentralized entities.

91 Wallace and Baños Smith 2010b.

92 Wallace and Baños Smith 2010b, p.140. 
laborate with and "was reliant on the research teams, who wrote the majority of the research reports. ${ }^{\prime 93}$ Embedded in the IS campaign's department, the team was initially lead by the former IWN coordinator and was composed of "many of the early "gender pioneers" from within the IS." "The members of the first Campaign Team were mainly female officials formally organized in the IWN. Thus, in contrast to the members of the second Campaign Team who coordinated the campaign from 2006 onwards, the members of the first team were senior IS staff possessing consolidated knowledge and expertise in women's rights issues. Indeed, many of them had previously lobbied the organization to increase its work on women's rights.

The campaign reviewer highlighted that all primary team members left in the beginning of the second phase of the campaign, and a new team composed of less experienced and less senior staff was nominated for campaign coordinator. ${ }^{95}$ The latter was led by Widney Brown (formerly responsible for women's issues at HRW and Senior Director of the International Law and Policy department at the IS). At the end of the campaign, the Campaign Team was dissolved and most of its members left AI, with others being integrated into other IS departments. While it was not clear how the work on issues of VAW was to be continued in the aftermath of the SVAW campaign, some of the Campaign Team's work was handed over to the newly created Gender, Sexuality, and Identity Program, which replaced the Gender Unit at the end of the campaign. ${ }^{96}$

Established in 2003, the Gender Unit can be traced back to an initiative of AIUSA ${ }^{97}$ and to the lobbying of the IWN. In fact, as an interviewee explains: "The Gender Unit itself was a product of campaigning by the movement and the women's network within AI."98 Mainly composed of two people, the Gender Unit "[was] situated in different institutional locations" ${ }^{99}$ before being attached to the policy and evaluation program. It was in charge of developing the SVAW campaign and providing policy advice both for it and for AI's work on women and human rights in general. It was also initially responsible for

\footnotetext{
93 Wallace and Baños Smith 2010b, p.140.

94 Wallace and Baños Smith 2010b, p.140.

95 Ganzfried: Interview with A.Z., 26.06.2012.

96 Wallace and Baños Smith 2010b, p.144.

97 Amnesty International, International Secretariat: Report and Decisions of the 24th International Council of Amnesty International, 21.08.1999, p.16.

98 Ganzfried: Interview with A.W., 25.06.2012, p.1.

99 Miller 2006, p.26.
} 
the GAP before handing this responsibility over to the deputy SG. ${ }^{100}$ Thus, the members of the Gender Unit collaborated "with colleagues [from the policy and evaluation program] on all policy issues connected with gender"101 and commented on SVAW reports. ${ }^{102}$

Further, an informant explained that the Gender Unit "was responsible for all the reports. Every report on SVAW went through [their] desk. And most of the sections' reports they invaded [the Gender Unit]. [...] So [the Gender Unit] worked with [the researchers] before, through the report, and worked with them after the report." 103 Because the IS team working on the legal standards of human rights was not sufficiently trained to frame the violations of women's rights within the appropriate legal principles, and because AI did not dispose of its proper policy defining the position of the movement regarding specific women's rights violations at this moment in time, the Gender Unit also had to provide the relevant international policy frameworks on women's rights for the IS research teams. For example, as one of my interviewees reported, AI did not have a position on the issue of "underage sex" or "child marriage," which made it difficult to do research and produce reports on these issues. ${ }^{104}$

Thus, the Gender Unit was responsible for many issues that had significantly changed over time, from "mainstreaming across all AI, strateg[y] for SVAW campaign, [and directing the] short period leading the Campaign, to

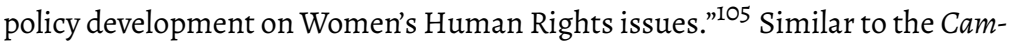
paign Team, the Gender Unit relied on collaboration with the legal teams and the research teams at the IS. The Gender Unit also dissolved at the end of the SVAW campaign and was replaced with the Gender, Identity and Sexuality Program. As I highlight later, AI suspended the head of the Gender Unit after she criticized the organization for taking on the defense of the extrajudicial detainee Moazzam Begg, who was known as a supporter of the Taliban. The

100 Amnesty International, International Secretariat: VAW Campaign progress update 28 July 2003, 28.07.2003, p.6; Wallace and Baños Smith 2010b. Amnesty International: Report of the meeting on: regional campaigning on SVAW wooc research projects in Europe, decembre 2005, p.16.

Amnesty International: Report of the meeting on: regional campaigning on SVAW wooc research projects in Europe, decembre 2005, p.16.

Ganzfried: Interview with A.W., 25.06.2012.

Ganzfried: Interview with A.W., 25.06.2012.

Miller 2006, p.26. 
former head of the Gender Unit argued that AI was risking its reputation on human rights with this association with Moazzam Begg. ${ }^{106}$

The Campaign Team's and the Gender Unit's institutional embeddedness into the IS and their lack of clear responsibility and power prevented the campaign from being effectively implemented. An interviewee described the functioning of the IS as: "It is like 300 organizations are all doing tiny ineffective things."107 Wallace and Baños (2010) stress the "lack of coordination around global campaigning" and "the strongly 'siloed' ways of working in the IS," which were exemplified by "different departments and teams focused on different women's rights issues, some under SVAW and some not, and there was no coherent picture of who was driving campaigning on what issue."108

Moreover, the SVAW campaign was also perceived within the IS as work extraneous to the rest of the headquarters' work. An interviewee explained the difficulty of mainstreaming a gender perspective into the IS's work with the fact that AI's work on VAW "was very much contained as 'that was in that campaign and the rest of our work is entirely separate."'109 Situated in the campaign department's policy and evaluation programs, respectively, the Campaign Team and the Gender Unit were detached from the research program and the legal program, where researchers undertook research that nurtured the campaign and the legal bases of Al's work on human rights were elaborated. Thus, the Campaign Team had to work horizontally with other departments across the IS, ${ }^{110}$ and the Gender Unit had to collaborate closely with the legal teams.

Often, informal contacts compensated for the absence of formalized collaboration between the Campaign Team and other departments. Eventually, they were pivotal for the achievements of the campaign objectives. The campaign review (2010) highlights that: "The relationships fostered [across the departments] appear to have depended on individual initiatives rather than being formalized in any way."111

While there had been good and frequent dialogues between the Campaign Team and other departments (most notably the regional and policy teams),

\footnotetext{
106 Daily Mail Reporter 2010.

107 Ganzfried: Interview with A.Z., 26.06.2012.

108 Wallace and Baños Smith 2010b, p.140.

109 Ganzfried: Interview with A.Z., 26.06.2012.

110 Miller 2006, p.27.

111 Wallace and Baños Smith 2010b, p.146.
} 
and the collaboration between the Campaign Team and the Gender Unit was rather positive, ${ }^{112}$ these entities' lack of clear responsibilities and authority hampered the implementation of the campaign. Indeed, there had been "a confusion over the role of the SVAW team as compared with the Gender Unit" ${ }^{\text {"113 }}$ and over the two entities' roles and responsibilities, as well as over how both of them were linked to the IS's other functions. ${ }^{114}$ The campaign review points out that "both [for example] commented on all documents relating to women's rights." ${ }^{115}$

However, the lack of power seems to have been particularly problematic for the work of the Campaign Team and the Gender Unit. An interviewee explains: "The SVAW team had the responsibility for [the coordination of the campaign] but they had no power, no power to make anything happen."116 Another interviewee refers to the Campaign Team's difficulties from the position of a team member: "So you are left saying 'I am going to lead this campaign but I have no research to lead it with."'117 The team's dependence upon the research teams and the fact that "the team had little authority over the organization's research agenda"118 made campaign coordination difficult.

Similar to the Campaign Team, the members of the Gender Unit also lacked authority and power. An interviewee reports that, "the Gender Unit [...] just cannot go to someone and say you need to change your research a little, do this and that so it deals with women's rights."119 Instead, "the research teams had to do some things on women's rights. But it was pretty much up to them what they did, how they did and when they did and where they did it."120 The Gender Unit's lack of accountability and authority entailed that collaboration was voluntary, which made its work even more difficult. An interviewee explains: "sometimes [the research teams] just did what they like and didn't tell us. [...] If they were good, they came to us to plan [the reports]. If they weren't so good, they just went off on a mission and sent it to us later." ${ }^{\text {212 }}$ The first ex-

112 Wallace and Baños Smith 2010b, p.141.

113 Wallace and Baños Smith 2010b, p.145.

114 Miller 2006.

115 Wallace and Baños Smith 2010b, p.145.

116 Ganzfried: Interview with A.Z., 26.06.2012.

117 Ganzfried: Interview with A.Z., 26.06.2012.

118 Wallace and Baños Smith 2010b, p.140.

119 Canzfried: Interview with A.Z., 26.06.2012.

120 Ganzfried: Interview with A.Z., 26.06.2012.

121 Ganzfried: Interview with A.W., 25.06.2012. 
ternal evaluation of the campaign revealed that the absence of responsibilities and authority also was a problem for the implementation of the internal campaign. In fact, according to Miller (2006), one of the reasons why AI failed to realize the internal campaign objectives was "the lack of strong signals from senior management on the implementation of the GAP,"122 and the fact that no one had the ultimate authority and responsibility to implement it. ${ }^{123}$

In summary, the Campaign Team's and the Gender Unit's detachment from the research program and the legal program, which were both key for AI's overall work because they lay the factual and legal basis for all activities and actions of the organization, and their lack of clear responsibilities and power hampered the work of these centralized entities of the SVAW campaign Machinery and, consequently, the implementation of the campaign. Furthermore, it is worth assuming that the composition of the staff of the Campaign Team and the Gender Unit influenced the implementation of the campaign in qualitative as well as quantitative terms. According to some IS staff members, the fact that the Campaign Team was composed of some very strong people during the first campaign phase hampered the collaboration with other IS teams. ${ }^{124}$ At the same time, the first team greatly contributed to the success of the campaign: "the team's commitment, knowledge and expertise added value to the campaign" and "played an essential role in supporting [sections] to produce campaign strategies."125 Consequently, the composition of the first Campaign Team somehow compensated for the team's detachment from the research program and the absence of clear responsibility and authority.

However, as the following extract from the campaign review shows, the problematic embeddedness of the team and its lack of authority and support played an important role in the first campaign team's decision to leave. The staff of the Campaign Team left at the end of the first campaign phase because they "were exhausted and felt they did not have the authority or resources to fulfill their responsibilities well, and they were not sufficiently supported to implement a major complex global campaign." ${ }^{.126}$ As I have already mentioned, they were replaced by less senior staff that an interviewee qualified

\footnotetext{
122 Miller 2006, p.26.

123 Miller 2006, p.26.

124 Wallace and Baños Smith 2010b, p.141.

125 Wallace and Baños Smith 2010b, p.141.

126 Wallace and Baños Smith 2010b, p.141.
} 
in the following way: "They just weren't senior enough. Not even vaguely senior." ${ }^{127}$ According to her, because the Campaign Team was junior, they lacked the authority and respect necessary to continue effective coordination. ${ }^{128}$ As far as the Gender Unit is concerned, the team's temporary understaffing and its under-qualified replacement hampered the Unit's effectiveness. In an interviewee's words: “They didn't replace her. [Instead] they gave somebody the brief [...] along with all their other work [...] who had no idea of women's rights." ${ }^{129}$

The preceding paragraphs have illustrated the pivotal role the Campaign Team and the Gender Unit played in the running of the SVAW campaign and have highlighted how their problematic embeddedness in the IS and the absence of clear responsibility and authority made their work difficult. Before concluding this section, I briefly describe the role of the SVAW network and the Campaign Steering Committee in the campaign's implementation.

The SVAW network was set up to facilitate the circulation of information from the IS to sections, thereby enhancing the capacity of the movement to campaign on VAW. ${ }^{130}$ It was thus mostly composed of the Campaign Team and the Gender Unit as well as of the sections' SVAW campaign coordinators. In fact, according to one interviewee, the SVAW network was basically "the contact person in each section and structure [the Campaign Team] would send stuff to."131 The campaign evaluation highlighted that, because the sections involved in the SVAW campaign were not required to provide feedback on their work to the Campaign Team, the sharing of information about the campaign was often "done in an ad hoc way, often through the SVAW network."132 While one interviewee saw the SVAW network as an extension of the IWN, explaining that:

"the SVAW network was an attempt to expand the IWN. With the [possibility] that men could join meetings as well, sections could join as well and that it

\footnotetext{
127 Ganzfried: Interview with A.Z., 26.06.2012.

128 Ganzfried: Interview with A.Z., 26.06.2012.

129 Ganzfried: Interview with A.W., 25.06.2012.

130 Amnesty International: Al and a new international women's rights network, November 2009.

131 Ganzfried: Interview with A.Z., 26.06.2012.

132 Wallace and Baños Smith 2010, p.146.
} 
would rally individuals and sections who could not find a feminist orientation as their comfort zone but would be willing to support VAW issues,"133

another interviewee suggested that the setting up of a network for the implementation of the SVAW campaign contributed to the dissolution of the IWN. According to her "the SVAW network was set up and money was put in to that [...]. So, it became a rival of [the IWN]." ${ }^{134}$ Nevertheless, given the lack of data on the SVAW network and the absence of any terms of references, it is worth assuming that it played a minor role in the running of the campaign.

However, at the end of the campaign, the sections' campaign coordinators took advantage of the network in order to pressure the organization into continuing its work on women's rights. ${ }^{135}$ In fact, as pointed out by one of my interviewees, many section campaign coordinators "[...] were in danger of losing their jobs because the SVAW campaign was closing. So, there were women who [...] when the SVAW campaign ended, were looking unemployment in the face." ${ }^{136}$ The same informant pointed out that they:

"protested and [...] they said that 'look, you know we need to have resources to do further work on women's human rights.' [...] They weren't just fighting for their jobs, they were fighting on the principled issue of 'can't just say SVAW is gone, ok, we will do other work."'137

While a part of the Campaign Team's and the Gender Unit's former staff continued working at the IS in a different function, it is not possible to say with certainty what happened to the campaign coordinators within sections. The function of the campaign coordinator of the Swiss section was transformed into a permanent position. It is worth assuming that other sections did the same for their campaign coordinators. However, the lack of information prevents us from making this conclusion with certainty. Similar to what happened to the Campaign Team and the Gender Unit, the SVAW network as such disappeared at the end of the SVAW campaign. However, the former members of the SVAW network at the IS and in different sections formed a new network called the International Women's Human Rights Network in 2011. It sought to "mobilize and strategize on women's human rights at a time when

\footnotetext{
133 Ganzfried: Interview with A.O., 23.01.2015.

134 Ganzfried: Interview with A.W., 25.06.2012.

135 Ganzfried: Interview with A.W., 25.06.2012.

136 Ganzfried: Interview with A.W., 25.06.2012.

137 Ganzfried: Interview with A.W., 25.06.2012.
} 
many are concerned that the gains that have been made in women's rights within AI may be lost." ${ }^{138}$

Similar to the situations described above, I also found very scarce data on the Campaign Steering Committee. None of my interviewees mentioned it when they talked about the SVAW campaign. It is thus worth assuming that it only played a marginal role in the overall running of the campaign. The little information that I did find had to do with its composition and general objectives. The Campaign Steering Committee was composed of senior section representatives, such as the Swiss section's secretary general, and of IS staff. It was meant to monitor and supervise the campaign, to develop lessons for future theme campaigns and "to improve communications and exploit more effectively the expertise and experience in the movement."139 Further, the committee was meant to enhance the commitment of the section directors and contribute to the endorsement of the campaign, particularly of the internal campaign.

Summing up, the organization's leadership initiated the majority of the ICM decisions concerning AI's work on VAW, and pushed AI's work on VAW from the top down with the SVAW campaign. The IWN, which had been initiated by female activists and which had been used as a strategy to make AI increase its work on women's rights throughout the 1990s, was dissolved in 2002. Many of the female officials were part of the feminist caucus at the IS and members of the IWN were included in the preparation and, particularly, in the implementation of the campaign as members of the SVAW campaign Machinery. However, the problematic embeddedness of the Campaign Team and the Gender Unit into the IS and their lack of clear responsibilities and power made it difficult for the women's rights advocates at the IS to effectively implement the campaign. Further, at the end of the first campaign phase, many of the "gender pioneers" at the IS left AI. Others quit at the very end of the campaign in 2010. Thus, it is worth assuming that with the SVAW campaign implemented from the top down, the female activists and officials who initiated AI's work on VAW in the 1990s lost their influence on the organization's work on issues of VAW. This loss of influence can therefore be seen as one of the reasons why AI did not succeed in making women's rights part of its DNA through the SVAW campaign.

138 Amnesty International: Al and a new international women's rights network, November 2009, p.1.

139 Khan 2003, p.9. 


\subsubsection{Resistance against Al's work on VAW}

This section emphasizes AI members' and sections' reaction to and participation in the SVAW campaign and specifically focuses on the debates accompanying the adoption of the ICM decisions on sexual and reproductive rights and abortion. In doing this, I highlight the activists' and officials' resistance to the SVAW campaign and to the adoption of a policy on abortion. Section 8.1.4 begins by examining the opposition to the campaign and shows that three principal factors motivated it. First, some of Al's members and officials opposed the SVAW campaign because they primarily perceived it as a flagship for the change that the adoption of the mission brought about. Second, other criticisms related to the structure and the setting of the campaign, rather than to its content. Third, some opposition related to the content of the campaign itself. Later, I highlight the critiques and the resistance to the adoption of the policy on abortion. This opposition can more clearly be identified as opposition to the issue of abortion and less to AI's overall policy change.

\subsubsection{Resistance against the SVAW campaign}

The 2001 ICM heralded many fundamental changes related to the content of AI's work and to its working methods. By adopting the mission, AI increasingly focused on economic, social, and cultural rights. The organization gave its concentration on individual cases up and opened out to thematic campaigning. At the same time, it increasingly engaged in collaborations with other organizations and abandoned the WOOC rule.

As its first long-term global thematic campaign, AI used the SVAW campaign as a flagship to test these transformations. The campaign thus served to probe the new way of thematic campaigning and to gain experience in giving sections the chance to conduct research on their own country. Evidence shows that part of the staff opposed the campaign because it embodied a departure to a new way of working on human rights and, consequently, a break with the past. An interviewee explained the opposition to the campaign with its "flagship role" in establishing a new way of working under the mission. The same person explained that the fact that the campaign "was used to drive many other things [...], made the campaign very unpopular for a lot of people."140 Kelleher and Bhattacharjya (2013) accurately explain that: 
"the opposition to this [the SVAW campaign] also was not necessarily a misogynistic response at the time, [but] more to the broadened mandate, the feeling that $\mathrm{Al}$ was entering waters it did not have enough expertise in, and that the reasons for doing such work were not clear [...]." ${ }^{n 14}$

Relatedly, the collaboration with external specialists on women's rights, inevitable when AI started dealing with a new thematic issue, posed problems to the IS staff. An interviewee explained that "there was a general kind of resistance to work with anyone else." ${ }^{142}$ In fact, as mentioned before, collaboration with external women's rights specialists was an integral part of the various campaign preparation meetings. Because VAW was a new issue, most IS staff had little or no experience in addressing it in their work, and campaign IS staff was required to collaborate with and learn from women's rights specialists external to AI during the Stop Violence against Women campaign. In his 2006 book Keepers of the flame, Hopgood explained the internal opposition against the SVAW campaign with the incompatibility between AI's original focus and the complexity of VAW. He argued that:

"Violence against women is complex; violence against women takes many forms, has many justifications and excuses, and is politically fraught locally and contentious globally. What would a simple illustrative case be? [...] But Amnesty aims to speak for women everywhere in the name of universal human rights. What case can it choose that truly reflects the core intuition, the very spirit, of universal rights? The founders, [...], had found one: the prisoner of conscience. That Amnesty identified with humanity as a whole-genderless, colorless, without sexuality-had been its virtue."143

Thus, according to him, there was an antagonism between AI's original focus and the complexity of VAW, which explains the challenge that the SVAW campaign presented to the organization and the internal opposition it evoked because, as he explained, "Amnesty [could not] continue to be what it has been as a result." 144

As highlighted previously, the SVAW campaign was implemented in two phases with distinct thematic focuses. Evidence indicates that the modification of the thematic emphasis between the first and the second part was

141 Kelleher and Bhattacharjya 2013, p.5.

142 Ganzfried: Interview with A.Z., 26.06.2012.

143 Hopgood 2006, p.154-155.

144 Hopgood 2006, p.154-155. 
subject to critiques from staff and activists. In fact, officials and activists criticized abandoning the focus on "VAW in armed conflicts" and "Domestic violence" at the end of the first phase. According to them, this change prevented the organization from continuing to build expertise and networks around these issues. As a result, many staff and activists simply ignored the campaign's new direction and carried on doing what they had been doing during the first phase of the campaign, because they did not understand the changes. ${ }^{145}$

For another interviewee, in the second phase "the campaign lost in international coherence [because] beside the girls-action [...], no strong campaigning line was visible." ${ }^{146}$ Further, as mentioned before, the last two years of the SVAW campaign coincided with the preparation of AI's second global thematic campaign Demand Dignity, which was launched at the beginning of 2009. Relatedly, as the evaluation of the SVAW campaign pointed out, "there was never a clear exit strategy for the campaign or for ending the work with partners." ${ }^{147}$ Thus, while not necessarily provoking opposition, the change of the thematic focus away from a unique emphasis on VAW toward becoming an instrument for achieving AI's growth agenda during the second phase, the absence of a clear exit strategy, and the related parallel launch of the Demand Dignity campaign made the SVAW unpopular among staff and activists.

While it is difficult to grasp the IS's opposition to the SVAW campaign in its entirety, the data allow us to locate the resistance and identify the main reasons behind it. Evidence indicates that opposition came from certain groups of researchers at the IS. One interviewee explained that as "traditional researchers, many of them, did not want to look at women's rights. Did not, would not." ${ }^{148}$ Another interviewee highlighted: "a certain research group [...] just didn't take it seriously. They were not interested. They didn't really think that women's rights were an issue in the Middle East for example." ${ }^{149}$ Some researchers refused to integrate a gender perspective into their reports, saying that "[they] d[id]n't have the capacity," 150 whereas others were "only open to incorporate a gender analysis if Gita [the head of the

\footnotetext{
145 Wallace and Baños Smith 2010b, p.139.

146 Amnesty International: Evaluation Kampagnenprojekte 2008, 16.01.2009, p.3.

147 Wallace and Baños Smith 2010b, p.179.

148 Ganzfried: Interview with A.W., 25.06.2012.

149 Ganzfried: Interview with A.Z., 26.06.2012.

150 Ganzfried: Interview with A.O., 23.01.2015.
} 
Gender Unit] would go with them on a mission. And back after the mission, Gita would write the section on gender."151

During the campaign, there were regular conflicts between the Gender Unit and the legal program, which could also be interpreted as a form of opposition to the SVAW campaign coming from some legal staff members. An interviewee explained: "[the Gender Unit was] constantly on battle with our own legal program because they hadn't got a clue about the legal standards related to women's human rights." ${ }^{152}$ The conflict between the Gender Unit and AI's legal and policy experts became manifest in the elaboration of Al's policy on abortion. The Gender Unit submitted a document on the absolute denial of abortion in Nicaragua to the UN Committee Against Torture, considering this denial a form of torture. An informant explains that "several of AI's legal and policy experts were furious" 153 with it, as the submission was a public document and did not reflect the state of AI's position on the issue at that time. However, as the following statement of the same interviewee demonstrates, the legal program's critique of applying black letter laws, such as the UN Convention against Torture, to issues of women's rights reflects a disregard of women's rights issues compared to the traditional human rights issues that AI had focused on before. According to this informant:

"if [the Gender Unit was] trying to use the issue of torture for women's rights it was treated as if [they were] using an inflationary language. [...] this is too precious to be applied to issues of women. It has to be applied to serious things like male political prisoners and so on."154

How can this content-related opposition against the SVAW campaign be accounted for? While it is difficult to definitively establish the reason behind this opposition, evidence indicates that it had to do with the patriarchal mentalities of some of the IS staff. Bhattacharjya identified "patriarchal mindsets" ${ }^{155}$ behind the internal opposition and contestation of the SVAW campaign. Kelleher and Bhattacharjya further explained that many women within AI perceived the functioning of AI to be "deeply patriarchal." ${ }^{156}$ Comparing AI

151 Ganzfried: Interview with A.O., 23.01.2015.

152 Ganzfried: Interview with A.W., 25.06.2012.

153 Ganzfried: Correction of citations A.W., 22.08.2018.

154 Ganzfried: Interview with A.W., 25.06.2012.

155 Bhattacharjya 2013, p.5.

156 Kelleher and Bhattacharjya 2013, p.10. 
to a secular church, defining AI as "basically a church," 157 another interviewee provides a similar explanation for the organization's struggles with the incorporation of women's rights into its overall work. He stated: "And you know how well the church deals with women's rights, very, very badly. Because they think women's rights are not really important enough and it is not fundamental to what it is about. It is about some deeper thing." 158

Thus, while part of the resistances to the SVAW campaign had to do with its flagship role and the campaign's structure and setting, another part of the resistance (observed at least among the IS staff) was clearly linked to the content of the campaign. An explanation for this seems to be the presence of patriarchal mentalities among IS staff members. Or, given that the church as an institution deeply embodies a patriarchal culture more than any other organization, Al's resemblance to a church may also explain the internal resistance. The correlation between AI's resemblance to a church and the opposition to the SVAW campaign also becomes evident within sections. As I show in section 8.2.2, the German section's closeness to the church explains its virulent opposition to the campaign and to the adoption of an abortion policy at least to a certain extent.

\subsubsection{Resistance against the adoption of a policy on abortion}

By focusing on the ICM decisions directly concerning AI's work on VAW, the present section illustrates that "the debate on reproductive rights [...] was one of the most challenging periods for Amnesty [...]." 159 and that abortion was a highly controversial issue. In fact, as figure 12 illustrates, among the decisions directly concerning AI's work on VAW, only the decisions on sexual and reproductive rights that included the issue of abortion provoked debates at their respective ICMs (highlighted in the left column of figure 12). ${ }^{160}$

The first signs of disagreement about the extent to which AI should work on the issue of sexual and reproductive rights, including abortion, became

157 Ganzfried: Interview with B.R., 25.06.2012.

158 Ganzfried: Interview with B.R., 25.06.2012.

159 Ganzfried: Interview with A.O., 23.01.2015.

160 As the report from the 2005 ICM shows, debates heralded the adoption of decision 2 of the 2005 ICM. But, these discussions did not focus on Al's work on women in conflict, but concerned other aspects of the resolution not related to women's rights. For this reason, I classified decision 2 of the 2005 ICM among those not triggering debates. 
Figure 12: ICM decisions and related debates, 2002-2009

Decisions triggering debates among section delegates at the ICM

\begin{tabular}{|c|c|c|}
\hline & Yes & No \\
\hline 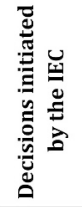 & $\begin{array}{l}\text { Decision } 32005 \text { ICM Sexual and } \\
\text { Reproductive Rights } \\
\text { Decision } 32007 \text { ICM Sexual and } \\
\text { Reproductive Rights }\end{array}$ & $\begin{array}{l}\text { Decision } 12003 \text { ICM Globalizing Justice! } \\
\text { Decision } 22005 \text { ICM The Protection of human rigths } \\
\text { through conflict prevention, intervention and } \\
\text { condemnation of force } \\
\text { Decision } 4 \text { ICM } 2009 \text { Commitment to long-term work on } \\
\text { behalf of individuals at risk, including prisoners of } \\
\text { conscience }\end{array}$ \\
\hline
\end{tabular}

Source: my own, based on the $2003,2005,2007$, and 2009 ICMs reports

evident in 2003. At the 2003 ICM, several South American sections (AI Argentina, AI Mexico, and AI Peru) initiated the discussion by emphasizing the importance of addressing sexual and reproductive rights when working on violence against women. AI Peru noted that this issue was particularly relevant in their region, where women were often denied the right of access to family planning. ${ }^{161}$ At the same time, concerned about AI's credibility with respect to the global SVAW campaign, the Irish section ${ }^{162}$ also called AI to further engage with the subject of abortion. ${ }^{163}$ Others, such as the Italian and the Indian sections, were more reluctant. The 2003 ICM report reflects that "the Italian section stated that they were not ready to enter into the area of abortion but were open to debate on the issue." ${ }^{164}$ The Indian section expressed concerns about how to campaign on the issue of abortion and suggested promoting the decriminalization of abortion but not the right to abortion. ${ }^{165}$ As I mentioned at the beginning of chapter 8 , the IEC launched a movement-wide consultation process with the aim of developing a common position in the aftermath of these initial discussions. Based on the results of the consultation,

161 Amnesty International, International Secretariat: Report and Decisions of the 26th International Council of Amnesty International, 2003, p.154.

162 Later, the same section proved to be more critical towards the adoption of an abortion policy.

163 Amnesty International, International Secretariat: Report and Decisions of the 26th International Council of Amnesty International, 2003, p.153.

164 Amnesty International, International Secretariat: Report and Decisions of the 26th International Council of Amnesty International, 2003, p.154.

165 Amnesty International, International Secretariat: Report and Decisions of the 26th International Council of Amnesty International, 2003, p.154. 
the IEC proposed its first enabling resolution to the 2005 ICM (illustrated in figure 13).

Figure 13: Origin of the two decisions on sexual and reproductive rights

\begin{tabular}{cccc}
\hline \multicolumn{4}{c}{ Resolutions preceding the ICM decisions on sexual and reproductive rights } \\
\hline ICM & Resolution & submitted by (author) & Resulting decision \\
\hline 2005 & HRS D & IEC & accepted in Decision 3 \\
\hline 2007 & HRS A & IEC & accepted as Decision 3 \\
\hline 2007 & HRS B & Peru & accepted as Decision 3 \\
\hline 2007 & HRS C & Italy and Sweden & accepted as Decision 3 \\
\hline 2007 & HRS D & Germany & accepted as Decision 3 \\
\hline
\end{tabular}

Source: my own, based on the 2005 and 2007 ICM reports

The report of the 2005 ICM reveals the sensitivity of the issue: "The Chair [reminded] the Working Party that this topic was very sensitive and urged a respectful debate."166 The discussion of the enabling resolution at the 2005 ICM illustrates the diverging viewpoints, which mostly crystallized on the issue of abortion. In fact, many sections feared that adopting a position on abortion at this moment would result in the drop-out of many AI members. While the delegates agreed that "the IEC [would] develop a policy showing AI's commitment to defending and promoting sexual and reproductive rights within its mission," 167 section representatives disagreed about abortion. While a majority (28 sections) called for further movement-wide consultations before developing a definite position, 19 sections favored the principle of legal, safe and accessible abortions for all women (this position was also espoused by the IEC), another 16 sections chose a position in line with the international legal consensus (i.e. where abortion was legal, it should be safe and where it was illegal, it should be decriminalized), and a minority of five sections favored a position stipulating that AI should only address a woman's right to abortion in instances of sexual assault, rape, and incest. ${ }^{168}$ Further, the sections disagreed on the process of reaching a consensus on this issue.

166 Amnesty International, International Secretariat: Report and Decisions of the 27th International Council of Amnesty International, 14th-20th August 2005, p.74.

167 Amnesty International, International Secretariat: Report and Decisions of the 27th International Council of Amnesty International, 2006, p.69.

168 Amnesty International, International Secretariat: Report and Decisions of the 27th International Council of Amnesty International, 2006, p.67. 
While half of the sections were in favor of adopting a position at the 2005 ICM, the other half wanted additional consultations, arguing that a decision was premature. ${ }^{169}$ Therefore, they opposed the IEC's enabling resolution and wanted to postpone the adoption of a definite position until the 2007 ICM. The divergence around decision 3 of the 2005 ICM thus concerned both the decision-making process and the content of AI's position on abortion. Consequently, the issue was postponed until the 2007 ICM, giving sections additional time for discussion.

However, as the submission of three section resolutions and one enabling resolution to the 2007 ICM (illustrated in Figure 13) shows, two years later, sections still disagreed on AI's future work on sexual and reproductive rights and abortion. AI Germany formulated the most critical position, suggesting that "AI will keep its neutral position on whether or not abortion should be a right of the woman." ${ }^{170}$ As one of the German delegates highlighted at the 2007 ICM, "It was very clear that the German section was perceived pretty much as trouble-makers in this matter"171 by the rest of the movement. The German resolution revealed a conservative understanding of a woman's right to end or not end her pregnancy, which juxtaposed fetal rights with maternal rights, stating:

"the possibility of fetal rights [...] is contentious and has medical, legal, and ethical facets. Experience with decades of discussions around this issue have shown that individuals, societies, and states cannot come to an agreement in the potentially tragic conflict woman-fetus." ${ }^{172}$

The German section explained its reticence to take a position on abortion with its members' belief in the importance of the question of whether "a fetus has a right to life."173

169 Amnesty International, International Secretariat: Report and Decisions of the 27th International Council of Amnesty International, 2006, p.73.

Amnesty International, International Secretariat: 28th International Council Meeting Circular 42 Resolution and Statute Amendment Pack, July 2007, p.12.

171 Ganzfried: Interview by Skype with A.C., 26.04.2015: "Es war aber ganz klar, dass man uns, die deutsche Sektion wahrgenommen hat als ziemliche Störenfriede in dieser Angelegenheit.".

172 Amnesty International, International Secretariat: 28th International Council Meeting Circular 42 Resolution and Statute Amendment Pack, July 2007, p.13.

173 Amnesty International, International Secretariat: 28th International Council Meeting Circular 42 Resolution and Statute Amendment Pack, July 2007, p.13. 
In its resolution, the Swedish section adopted the position most contrasting with the German position. This stance, also shared by the IS, ${ }^{174}$ asked for an evaluation of the current policy on abortion as to whether it fitted AI's future work on the right to health, a main issue within the upcoming Demand Dignity campaign. It also raised the possibility of addressing the global problem of "maternal deaths, [which] are due to unsafe abortions." 175 In its resolution, AI Peru (Figure 13) proposed "a policy on access to quality services for the management of complications arising from abortion,"176 arguing that such a policy did not mean that AI agreed with abortion or with the decriminalization of abortion. Instead, it would guarantee the right of access to health care that every person should enjoy.

At the same time, in its enabling resolution, the IEC demanded the adoption of the policy on selected aspects of abortion (decriminalization of abortion; access to quality services for the management of complications arising from abortion; legal, safe, and accessible abortion in cases of rape, sexual assault, incest, and risks to a woman's life). After some discussion in the working party at the ICM, the delegates finally reached a compromise, and the final resolution (HRS A) was accepted by a large majority to become decision 3. Nevertheless, a small minority (seven votes, which included the Irish, the Venezuelan, and some African sections) still firmly disagreed with the adoption of any policy on abortion. ${ }^{177}$ Even though it shared this disagreement, the German section finally grudgingly accepted decision $3 .{ }^{178}$

In sum, AI took more than six years to find a common position on the issue of abortion. The length of the decision-making process reflects the important opposition of some of AI's members and staff to the adoption of an AI policy on abortion. While the analysis of the ICM reports allows us to understand the decision-making process, the reports do not allow us to identify each section's position. We are, however, able to recognize some regional tendencies thanks to personal interviews. According to one of my interviewees, many Latin American country sections were in favor of adopting a position on

\footnotetext{
174 Ganzfried: Correction of citations A.C., 30.07.2018.

175 Amnesty International, International Secretariat: 28th International Council Meeting Circular 42 Resolution and Statute Amendment Pack, July 2007, p.9.

176 Amnesty International, International Secretariat: 28th International Council Meeting Circular 42 Resolution and Statute Amendment Pack, July 2007, p.8.

177 Amnesty International: 28th international Council Meeting, 2007.

178 Ganzfried: Interview by phone with A.Y., 09.01.2015.
} 
abortion. She explained that "Interestingly the sections in Latin America had no problem with putting abortion [on the agenda]." ${ }^{n 179}$ Similarly, the Nordic sections, such as the Swedish, the Norwegian, and the Danish sections, favored a position in favor of the decriminalization of abortion. In contrast, as I have already illustrated, the German section opposed any policy-making on the issue for many years. Further, African sections seem to have been rather critical of the adoption of the policy.

One of the reasons why some sections strongly opposed the adoption of any position on abortion was their fear of losing members. Speaking on behalf of the critical sections, an interviewee explained: "If we do this, the members are going to go. [...]. They were scared, who is going to give the money?"180 There were cases of long-term activists leaving their sections and the organization when AI adopted its policy on the restricted aspects of abortion. In fact, because of AI's nature of a membership organization based on democratic principles that gave members the opportunity to define the organization's working focus, the attitude of a section's membership towards the issue was paramount for the section's position on AI's policy on abortion. It seems that the traditionally conservative membership, manifest, among other things, in the section's closeness to the Church, explained its opposition to the adoption of an abortion policy, at least in the case of the German section.

In fact, according to an informant, the members of the German section were rather conservative and close to the Church: "It just shows you the type of people and how the organization grew because in the North, interestingly enough, because it all started with Church and going with little groups in the Church here in this country in Germany or whatever." 181 In contrast, the same interviewee explains, Latin American AI sections were generally in favor of adopting an abortion policy because of their progressive membership:

"you can think 'Latin America is very Catholic.' But the people in Latin America who would become members of Al belong to a kind of elite, the middle classes. [...] University students, they are the ones who are becoming members, not the conservative people. [...] The Latin American sections are new ones; the members are university people [...]."182 
My data thus points to a relationship between a section's church-related membership and its willingness to integrate issues of VAW into its work. As I highlight later, this relation is also reflected in the case studies on the German and the Swiss sections.

Summing up, activists and officials put up real resistance to the SVAW campaign and to the adoption of a policy on abortion. In the case of the SVAW campaign, staff and activists also opposed the campaign for reasons other than its content. In the case of the discussion on the ICM decisions on sexual and reproductive rights, the resistance was clearly related to the issue of abortion itself. I therefore argue that the content-related opposition against the SVAW campaign and against the adoption of a policy on abortion were an important reason for AI's failure to integrate VAW into its work through the SVAW campaign.

So far, the analysis at the international level indicates that it is worth assuming that AI did not succeed in integrating VAW into its work through the SVAW campaign for two main reasons. First, female activists and officials who initiated AI's work on VAW in the 1990s lost their influence on the organization's VAW work. Second, activists' and officials' resistances to the SVAW campaign and to the adoption of an abortion policy was too strong to be neglectedAs I demonstrate in the following pages, there were considerable differences in the extent to which AI succeeded in integrating the issue of VAW into its work at the national level, in the section's reactions to the participation in the SVAW campaign, and in the opposition to the adoption of an abortion policy. I examine all of these issues in my case studies on the Swiss and the German sections.

\subsection{The national levels}

My focus on the national level allows me to examine the considerable differences in the extent to which the Swiss and the German sections managed to integrate the issue of VAW into their work in the 2000s. While the Swiss section was more successful in making VAW part of its overall work, the German section hailed limited achievements. Chapter 8.2 provides a detailed picture of the content and the structures supporting the sections' work in the frame of the SVAW campaign. It identifies five criteria that allow me to capture each section's success in integrating VAW into its work. The criteria emerged from the data and have to do with the adoption of the overall campaign by the sec- 
tion; the professionalization of the work on issues of VAW; the leadership's commitment to the SVAW campaign; the influence of a section's women's group or network on the section's work on issues of VAW; and lastly, the section's resistance to the SVAW campaign and the adoption of the abortion policy. In the chapters on the Swiss and the German sections, I demonstrate the extent to which the two sections met these criteria. In conclusion, the present chapter tries to explain the success of the Swiss section and the difficulties of the German section in making VAW part of their overall work by coming back to the central differences between the two sections. I argue that the German section members' relative closeness to the Church and their comparatively powerful position help explain the difference between the two sections.

\subsubsection{The Swiss section}

The present section demonstrates that even though the review of the overall SVAW campaign showed that AI did not succeed in making VAW part of its overall work, this general finding has to be nuanced. The Swiss AI section succeeded in doing so at least partially through the SVAW campaign. The section starts by providing a detailed picture of the Swiss section's campaign and illustrating where the section put the latter's thematic focus. It also details the activities realized within the frame of the campaign. It quickly becomes evident that the Swiss section adopted the thematic focus of the overall campaign and launched an internal as well as an external campaign. Section 8.2.1 then highlights the section leadership's commitment to the SVAW campaign and demonstrates the continued importance of the section's women's network for the work on violence against women. The section shows that despite the top-down implementation of the campaign and the professionalization of the work on VAW at the Swiss section, the female activists and officials of the women's network remained important in defining the section's work on the issue. Then, I focus on the section's participation in and reaction to the SVAW campaign, as well as on the internal discussions regarding the elaboration of the abortion policy. I demonstrate that resistance to the issue of VAW from activists and officials was isolated at the Swiss section. At the same time, the section shows that even though most of the groups participated in the public SVAW campaign, their involvement was more pragmatic than enthusiastic, and that work on VAW remained overwhelmingly confined to the members of the women's network. 


\subsubsection{Merging the international campaign strategy with the section's priorities}

In line with the overall campaign strategy, the Swiss section labeled the campaign Stoppt Gewalt Gegen Frauen, launched an internal campaign and implemented the public campaign in two phases. In contrast to the general campaign, the Swiss section launched the internal campaign and the public campaign simultaneously in 2004. It developed its own Gender Action Plan containing section-specific objectives on how to become a gender-sensitive organization, where gender aspects become a transversal theme in all campaigns and activities and where members engage with the principle that "women's rights are human rights." ${ }^{183}$ According to the section's management, the Gender Action Plan had to help in "making the organization internally coherent with its public discourse.,184 My interviews revealed that one of the key messages the Swiss section wanted to convey to its members through the Gender Action Plan was that the SVAW campaign should be perceived primarily as a human rights campaign, rather than as a feminist endeavor. Thus, the section's management thought it was pivotal to "[pay] attention to the fact that men were also bearers, bearers of the message"185 and to achieve a balanced representation of men and women within all positions at every level of the organization. ${ }^{186} \mathrm{~A}$ long-term official explained: "when there were applications, of course they had to be of equal qualifications, but there was however a specific will to say 'in cases of equal qualifications, we want and we will clearly privilege women's applications for the management board." ${ }^{187}$ In order to enhance the members' gender awareness, the section organized various workshops with external gender specialists. ${ }^{188}$ Evidence shows that these workshops were supposed to make staff and activists reflect on their gender roles

\footnotetext{
183 Jegher: Der Cender Aktionsplan Schweizer Sektion (CAP-Al CH), 18.12.2003.

184 Amnesty International: Plan d'action Cenre de la Section suisse, 17.03.2004, p.2.

185 Ganzfried: Interview with A.]., 09.03.2012: "On a toujours fait attention à ce que les hommes soient aussi porteurs, porteurs de message.".

186 Jegher: Der Gender Aktionsplan Schweizer Sektion (CAP-AI CH), 18.12.2003.

187 Ganzfried: Interview with A.J., 09.03.2012: "Quand il y avait des postulations, bien sûr il fallait une qualité égale au niveau du dossier mais quand même une volonté spécifique qui a été dit 'nous voulons et nous privilégierons en cas de qualité égale, clairement les dossiers femme dans la Ceschäftsleitung.".

188 Jegher: AICH-Kampagnentagung 2005 - durch die Gender-Brille gesehen, 22.10.2005, p.1.
} 
and to sincerely address possible internal resistance to gender issues. ${ }^{189}$ As I emphasize later, the success of these workshops was moderate.

Around the $8^{\text {th }}$ of March 2004, the section also launched the public campaign starting with a media manifesto containing various national personalities' support messages and primarily followed by women's groups' activities. By May 2004, all AI groups had become involved. ${ }^{190}$ The Swiss section implemented the public campaign over the course of six years, from 2004 until the end of 2010. However, just like the overall campaign, the intensity of the campaign was higher during the first phase. ${ }^{191}$ Later, between 2008 and 2009, the SVAW campaign became one of four main global theme campaigns that the section was implementing. ${ }^{192}$ Relatedly, the campaign coordinator explained that the resources for her brief were reduced to about $50 \%$ in 2008 , which by

189 Amnesty International: Plan d'action Genre de la Section suisse, 17.03.2004, p.4.

190 Amnesty International: "Halte à la Violence contre les Femmes" Informations sur la campagne, Janvier 2004; SVAW Projekt Team AICH: Sitzungsprotokoll 12.2.2004, 12.02.2004. Whereas issues related to women's rights or to the SVAW campaign had been discussed at every CA between 2003 and 2006, the same issues disappeared from the CA's agenda or were only marginally mentioned at the 2007, 2008, 2009, and 2010 GAs (Amnesty International: Delegiertenversammlung 2002, 06.04.2002; Amnesty International: Delegiertenversammlung 2003, 12.04.2003; Amnesty International: Delegiertenversammlung AICH 2004, 14.05.2004; Amnesty International: Delegiertenversammlung 2005, 29.05.2005; Amnesty International: Protokoll der Delegiertenversammlung 6.-7. Mai 2006 in Delémont, 07.05.2006; Amnesty International: Delegiertenversammlung 2007, 06.05.2007; Amnesty International: Protokoll der Jahresversammlung 19. und 20. April 2008 Bern, 20.04.2008; Amnesty International: Procès-verbal de l'assemblée générale du 27/28 juin 2009 à Berne, 28.06.2009; Amnesty International; Amnesty International: Protokoll der Generalversammlung 2010 in Fribourg, 25.04.2010). The decline of the activities organized in the frame of the campaign could also be observed at the group level. In fact, screening 44 minutes from meetings of the Al group La côte revealed a declining frequency of the agenda item 'SVAW campaign' or 'women's rights' between 2004 and 2008. While these items were mentioned in $80 \%$ ( 17 out of 20 ) of the minutes of the meetings that took place between 2004 and the end of 2005, the same items only appeared in 54\% (13 out of 24) of minutes of meetings from 2006 until the end of 2008.

192 As reported in the minutes of the $2008 \mathrm{GA}$, in 2008 , beside the SVAW campaign, AICH put emphasis on the Campaign on Dignity, the campaign against the violations of the torture prohibition called Counter Terror with Justice, and the campaign for the respect of human rights at the Olympic Games in Beijing 2008 (Amnesty International 2008, p.11). 
that time was "not sufficient for a more important presence"193 of the SVAW campaign within the section.

The Swiss section broadened the thematic focus of the campaign, concentrating on "Women trafficking" and "Due diligence" in its first phase, ${ }^{194}$ in addition to the themes adopted by the overall campaign ("Domestic violence" and "VAW in armed conflicts"). ${ }^{195}$ In fact, in a consultation, the surveyed national women's rights organization qualified "Women trafficking" and "Due diligence" as important national VAW issues. ${ }^{196}$ Further, similar to the overall campaign, the section mainly emphasized "Violence in intimate relationships" in between the two main campaign phases. ${ }^{197}$

During the second phase, the Swiss section complied with the growth objectives of the overall campaign and defined the growth of its active membership as a means to the organization's effectiveness. ${ }^{198}$ At the same time, the section put a different emphasis on the objective "Human Rights concern" than that proposed by the IS. The section planned to work on the principle of due diligence, to lobby the Swiss government in favor of the ratification of the European convention against human trafficking, to participate in the internal discussion on AI's position on sexual and reproductive rights, and enhance the mainstreaming of women's rights throughout the section. ${ }^{199}$ In 2008 , aside from some smaller actions on the protection of female human rights defenders and on domestic violence, the section essentially focused on

193 Amnesty International: Evaluation Kampagnenprojekte 2008, 16.01.2009, p.3: "ausserdem reichten die deutlich verringerten Ressourcen seitens der Kampagnenleitung (nurmehrca. 50\%) nicht aus für eine stärkere Präsenz.".

194 Jegher: Kampagne Stoppt Gewalt gegen Frauen Mittelfristige Planung per Jan. 05 bis ca. März 06, 23.12.2004; Amnesty International: SVAW - Aktuell vom 7.4.2004 News zur Frauenkampagne Al CH, 07.04.2004; Amnesty International: Kampagnenplanung SVAW AlCH - Strategie- und Aktionsplan updated, July 2004.

195 The Swiss section named this issue "weapon and VAW".

196 In order to identify the campaign's priorities AICH asked more than 30 women's rights organizations and Equality Offices about the occurrence and the nature of genderbased discrimination and VAW in Switzerland. Bourquin: VAW Campaign External Audit, 2003.

197 Amnesty International: VAW in the family Progress update Swiss Section, 28.09.2006.

198 Amnesty International: Operativer Plan 2006-2007 (AICH OP 2) Wachstum und Wirkung unseres Einsatzes für die Menschenrechte, 24.04.2006.

199 Amnesty International: Operativer Plan 2006-2007 (AICH OP 2) Wachstum und Wirkung unseres Einsatzes für die Menschenrechte, 24.04.2006. 
women trafficking in a sub-campaign related to the European football championship, called "Euro 08 against Women Trafficking." 200 According to the campaign coordinator, with the women trafficking campaign, the Swiss section "stressed its own priorities" 201 and "did not take up the 'main' - girls - campaign" ${ }^{202}$ focusing on violence and the right to education, as defined in the overall campaign objective "Human Rights Concerns."

Within the frame of the aforementioned main thematic priorities, the Swiss section carried out numerous advocacy, lobbying and outreach activities. I briefly highlight some of the most important campaign activities realized by the Swiss section in an attempt to shed some light on them. In 2005, various local groups participated in a bicycle tour of the country, initiated by the Bern women's group, with the goal of sensitizing a large public to the issue of domestic violence. ${ }^{203}$ Further, in September 2005 , in what was one of the key moments of the campaign, the section organized an international conference on due diligence in collaboration with other organizations and institutions. ${ }^{204}$ In 2006, various local AI groups participated in the action called "mobile home against domestic violence," which strived to improve the state's interventions against family violence. A tour of the country's rural areas sought to sensitize the public and young men, in particular, to the issue of domestic violence. ${ }^{205}$ Moreover, in collaboration with other organizations, the Swiss section lobbied for the tightening of the Swiss legislation in matters of weapons. ${ }^{206}$ The Swiss section collaborated with the women's movement, just like the campaign's central organs tried to at the international level. ${ }^{207}$ Women NGOs, such as the Marche mondiale des femmes, the NGO-Koordination

200 Amnesty International: Evaluation Kampagnenprojekte 2008, 16.01.2009.

201 Amnesty International: Evaluation Kampagnenprojekte 2008, 16.01.2009, p.3: "Wir setzten mit der Frauenhandels-Kampagne eigene Akzente.".

202 Amnesty International: Evaluation Kampagnenprojekte 2008, 16.01.2009, p.3: "griffen die 'Haupt'-Girls-Kampagne nicht auf..'

203 Amnesty International: Velotour gegen häusliche Gewalt 3./4. September 2005 Ein Aktionsvorschlag der Berner Frauengruppe, 09.03.2005.

204 Amnesty International: Due Diligence: Rolle und Pflichten des Staates in der Bekämpfung von Cewalt gegen Frauen: Standards, Probleme, Perspektiven Internationale Fachtagung zur Kampagne "Stoppt Gewalt gegen Frauen" 21. bis 23. September 2005, 30.03.2005.

205 Amnesty International: VAW in the family Progress update Swiss Section, 28.09.2006.

206 Amnesty International: Notice from Stella Jegher to Caroline Huwiler on the SVAW updates, 06.08.2004.

207 Amnesty International: Kampagne Stop Violence against Women (SVAW) Strategie- und Aktionsplan Schweizer Sektion, 21.01.2004. 
Post Beijing, ${ }^{208}$ the umbrella organization of the Swiss shelters for women, ${ }^{209}$ the Fraueninformationszentrum FIZ, and ${ }^{210}$ the KOFF, ${ }^{211}$ as well as governmental organizations, such as the Federal Office for Gender Equality and the Federal Department of Foreign Affairs, were all among AI's partner institutions during the campaign. ${ }^{212}$

Summing up, the Swiss section implemented the SVAW campaign and adopted the themes of the overall campaign - "VAW in armed conflicts" and "Domestic violence," supplementing them with issues of VAW that were specific to its national context, such as "Women trafficking." The Gender Action Plan and the related workshop were the main components of the internal campaign strategy. ${ }^{213}$ During the second phase, the Swiss section focused on the issues of "Due diligence," "Women trafficking," and the internal discussion of AI's position on sexual and reproductive rights and continued the implementation of the GAP. Thus, the Swiss section successfully merged the section's priorities on issues of VAW with the international campaign strategy.

\subsubsection{The continuing importance of the women's network}

While the preceding section highlighted the content of the Swiss SVAW campaign, this section emphasizes how the section organized the latter's implementation. To do so, I call attention to the leadership's commitment to the campaign and demonstrate the continuing importance of the section's women's network for the work on VAW.

The section's management was committed to and pushed the SVAW campaign forward. The person in charge of the preparation of the campaign wrote: "the Swiss section can count on the clear support of the management" 114 when it faced the challenge of "training and mobilizing the entire

208 Amnesty International: Frauenrechts-Ko-Gruppe Sitzungsprotokoll vom 11. Juni 2007, 11.06.2007.

209 Dachorganisation der Schweizer Frauenhäuser.

210 SVAW Projekt Team AICH: Sitzungsprotokoll 5.8.2004, 05.08.2004, p.2.

211 Amnesty International: Evaluation Kampagnenprojekte 2008, 16.01.2009.

212 Bourquin: Préparation de la VAW - update/listing, 09.09.2003, p.4; Amnesty International: Evaluation Kampagnenprojekte 2008, 16.01.2009.

213 Jegher: Kampagne Stoppt Cewalt gegen Frauen Mittelfristige Planung per]an. 05 bis ca. März 06, 23.12.2004

214 Amnesty International: Campagne interne (objectifstratégique 4 de la VAW), 09.09.2003, p.3: "[L]a section peut s'appuyer sur [...] le soutien clair de la Direction générale de la Section pour les questions droits des femmes, [...].". 
section for [the issue of women's rights]"215 in September 2003. She further declared that: "it seems to be clear that the VAW campaign, and particularly the internal campaign, is part of a process coming from the top to the bottom." ${ }^{216}$ The campaign coordinator explained that the Executive Director (ED) "promoted women's rights within the Swiss section.." ${ }^{217}$ Further archival material suggests that in the beginning of the 2000 s, the ED and the members of the EC were dedicated to intensifying the section's work on women's rights and VAW and to integrating the issue into the section's activities in a sustainable way. In the response to the women's network's postulate to the $2003 \mathrm{GA}$, which called upon the section to take the measures necessary for a sustained integration of women's rights beyond the SVAW campaign, ${ }^{218}$ the management explained that "the EC and the ED [had] the very clear intention to make [women's rights] a permanent issue," 219 and confirmed their commitment to the organization of the internal campaign. ${ }^{220}$

Moreover, the EC was in favor of the creation of the Women's Rights Commission, ${ }^{221}$ which, as I detail later, was an initiative of the women's network and aimed at mainstreaming Al's work on VAW. Evidence also shows that the section's management particularly welcomed the internal campaign. The section's management commented on the overall strategy that: "[they] welcomed in particular the initiative of conducting an internal campaign in parallel with the public campaign that questions [their] own practice regarding women

215 Amnesty International: Campagne interne (objectifstratégique 4 de la VAW), 09.09.2003, p.3.

216 Amnesty International: Campagne interne (objectifstratégique 4 de la VAW), 09.09.2003, p.1: "Il semble clair que la campagne VAW et plus particulièrement la campagne interne, s'intègre dans un processus venant du haut vers le bas.".

217 Ganzfried: Interview with B.Q., 09.09.2011: "Auf Schweizer Ebene förderte Daniel Bolomey die Frauenrechte als Geschäftsleiter.".

218 Amnesty International: Prise de position du CE et du Secrétariat sur le Postulat A adopté par I'AD 2003 à Genève, 22.01.2003; Amnesty International: Protokoll der Vorstandssitzung vom 6. März 2003, 06.03.2003.

219 Amnesty International: Prise de position du CE et du Secrétariat sur le Postulat A adopté par I'AD 2003 à Genève, 22.01.2003, p.2: "I'intention très claire du Comité et du SG est d'en faire une problématique permanente".

220 Amnesty International: Prise de position du CE et du Secrétariat sur le Postulat A adopté par l'AD 2003 à Cenève, 22.01.2003.

221 Amnesty International: Protokoll der Vorstandssitzung vom 23.05.2002, 23.05.2005. 
rights [...]."222 Indeed, the section's leadership stressed the importance of the internal campaign in a letter to the whole section explaining that "the EC made the planning of the campaign and the section's GAP a huge priority."223

Another element that points to the commitment of the section's Executive Director (name of person) was his involvement in the planning of the campaign and its preparation at the international level. He was a member of the international Campaign Steering Committee, contributed to the delegates' mobilization for the campaign at the $2001 \mathrm{ICM},{ }^{224}$ and participated in the movement-wide campaign preparation meeting in Oxford in July 2003 at Irene Khan's request. ${ }^{225}$ On the whole, one can therefore conclude that the Swiss section's management was greatly committed to intensifying its work on VAW and advocated for the effective implementation of the SVAW campaign. At the same time, as the following section demonstrates, female activists and officials continued to play an important role in the section's work on issues of VAW, especially in further institutionalizing the work on VAW within the section.

As chapter 7.2.1 explained, female activists in the Swiss section formed a national women's network at the beginning of 2000 . In 2001, the women's network was composed of four local women's groups (Lausanne, Bern, Geneva, and Zurich) and a Kogruppe and handled the section's work on women's rights and VAW. As we can see, the network remained a driving force behind the section's work on VAW during the SVAW campaign. ${ }^{226}$ Figure 14 provides an overview of the entities involved in the section's work on VAW in the 2000 s. Besides the various women's groups (on the right side), some of which disappeared prior to the SVAW campaign, the campaign coordinator and the

222 Amnesty International: Campagne sur la violence envers les femmes Projet de stratégie 2004-2006, 2004, p.1: "Nous saluons tout particulièrement l'initiative de mener-parallèlement à la campagne public - une campagne interne qui interroge notre propre pratique en matière des droits des femmes, [...].".

223 Amnesty International: Plan d'action Genre de la Section suisse, 17.03.2004, p.2: "Le comité exécutif a accordé une grande priorité dans la planification à cette campagne et au Plan d'action sur le genre.".

224 Amnesty International: Prise de position du CE et du Secrétariat sur le Postulat A adopté par I'AD 2003 à Genève, 22.01.2003.

225 Amnesty International, International Secretariat: Violence Against Women Campaign Report on the International Strategy Consultation Meeting 18-20 July 2003 Oxford, UK, 05.08.2003.

226 The women's network meetings took place in 2002, 2003, 2005, 2007, 2008, 2009. 
Project Team guaranteed the implementation of the campaign between 2003 and 2010. All entities but the SVAW Project Team (on the left side) were part of the women's network.

Figure 14: Entities involved in the Swiss section's work on VAW in the 2000 s

\begin{tabular}{cc}
\multicolumn{2}{c}{ Women's network } \\
Kogruppe & Women's group Zurich \\
$(1999-2002)$ & $($ since 1998) \\
Women's Rights Commission & Women's group Bern \\
$(2002-2004)$ & (since 1998) \\
SVAW campaign coordinator & Women's group Lausanne \\
(since 2003) & (since 1998) \\
Ko-Gruppe Women's Rights & Women's group Geneva \\
(since 2006) & (since 2000)
\end{tabular}

Source: my own

Evidence shows that the women's network, initially composed of four local groups and the Kogruppe, originally pursued two main objectives: first, it sought to attain a broad commitment to and engagement in the work on VAW within the section. Second, the network wanted to professionalize the section's work on VAW. To realize the first objective, the members of the women's network founded the so-called Women's Rights Commission ${ }^{227}$. The professionalization of the section's work on VAW was achieved with the appointment of the SVAW campaign coordinator. In 2006, realizing that their role in the section's work on VAW was weakening, the members of the women's network reinitiated a coordination group (the Ko-Gruppe Women's Rights) that sought to bring the local women's groups back into play. By focusing first on the Women's Rights Commission, then on the SVAW campaign coordinator, and third on the Ko-Gruppe Women's Rights, the following paragraphs provide a detailed picture of the principal actors involved in the section's work on VAW from 2002 until 2010. They demonstrate that the members of the women's network influenced the section's work on VAW, despite the top-down implementation of the SVAW campaign and the related professionalization of the work on violence against women. 
The establishment of the Women's Rights Commission can be seen as an attempt to mainstream women's rights across the section's work initiated by the women's network. Following the dissolution of the Kogruppe 228 at its first national meeting in February 2002, members of the women's network came up with the idea of creating a commission able to better represent their concerns at the sectional level. ${ }^{229}$ The network members argued that the activities undertaken by the women's groups were not sufficient for "the integration of the issue of women's rights into the global work of AI."230 After the presentation of their idea of a women's rights commission, the EC recognized the new structural entity in May $2002 .^{231}$

Aside from its overall goal of "a better integration of women's rights,"232 the commission was meant to sensitize AI members and the public to women's rights, to link AI's work on women's rights to the national and international women's rights movement, to support other AI groups in their work on women's rights, and to promote awareness of and the respect for women's rights. ${ }^{233}$ As defined in its mandate, "the commission [was] composed of women and men who wish[ed] to engage with AI for women's rights" 234 and of a representative from each the secretariat, the EC, and each local women's group. 235

However, evidence reveals that the interest in the commission remained overwhelmingly limited to those female activists and officials already engaged in the section's work on women's rights. In fact, at the beginning of one of the meetings, the members of the commission claimed: "we all know each other! [We regret] that nobody new had joined."236 My findings indicate that the commission disappeared with the launch of the SVAW campaign ${ }^{237}$ because,

\footnotetext{
228 Details on this group can be found in chapter 7.2.1.

229 Morstein: Presentation of the Women's rights commission, 2002.

230 Amnesty International: Jahresbericht der Frauenrechtskommission (FRK), 2003, p.3.

231 Morstein: Presentation of the Women's rights commission, 2002.

232 Amnesty International: Jahresbericht der Frauenrechtskommission (FRK), 2003, p.3.

233 Amnesty International: Jahresbericht der Frauenrechtskommission (FRK), 2003.

234 Morstein: Presentation of the Women's rights commission, 2002, p.2.

235 Morstein: Presentation of the Women's rights commission, 2002.

236 Amnesty International: Protokoll der Frauenrechtskommission, 09.11.2002, p.1.

237 In fact, I could not find any minutes of the commission's meetings after April 2004 (Amnesty International: Protokoll Sitzung Frauenrechtskommission vom 3. April 2004 , 13.04.2004).
} 
as an official involved in the preparation of the campaign observed: "part of [the commission's] mandate [...] is covered by the campaign on VAW today." 238

As I show in the upcoming paragraph, the newly appointed campaign coordinator and the SVAW Project Team took over most of the commission's responsibilities. ${ }^{239}$ The Women's Rights Commission thus only existed for two years, and even though supposed to attract activists and officials beyond the circle of women's rights advocates, it overwhelmingly brought together the people already involved in the section's work on women's rights. Thus, the women's network's objective of ensuring a broad commitment to and engagement in women's rights within the section by installing a Women's Rights Commission was only partially achieved. In contrast, as the next paragraph illustrates, the network's objective of professionalizing the Secretariat's work on women's rights proved to be more fruitful.

Even though various officials had worked on issues of women's rights before, the professionalization of this work only became substantial with the appointment of the SVAW campaign coordinator in 2003. As mentioned in chapter 7.2.1, without having defined terms of reference, a campaigner had been "unofficially responsible for women's rights" 240 in addition to her other briefs at the section's regional office in Lausanne since the beginning of the 2000 s. $^{241}$ The person responsible for lobbying and the staff member responsible for Animation and Education at the secretariat in Bern were later assigned to participate in the preparation of the SVAW campaign. They were both charged with doing this in addition to their other briefs for the period between January and November 2003, again without a related job description. The section's management finally appointed a SVAW campaign coordinator in December 2003. With this appointment, the section's leadership sought to "provid[e] the best conditions for the realization of the internal as well as the external campaign and to guarantee the long-term integration of this issue in the Swiss section." 242

238 Bourquin: Préparation de la VAW-update/listing, 09.09.2003, p.3.

239 Amnesty International: Procès-verbal de la réunion du 8 février 2003, 08.02.2003.

240 Amnesty International: Internal Audit Campaign on violence against women, November 2002, p.1.

241 Bourquin: Journée nationale du réseau femmes de la Section Suisse, 02.02.2002; Ganzfried: Conversation with C.D., 10.02.2017.

242 Amnesty International: Prise de position du CE et du Secrétariat sur le Postulat A adopté par l'AD 2003 à Genève, 22.01.2003, p.2: "afin de nous donner les meilleures conditions pour 
Evidence indicates that the campaign coordinator was important for the success of the SVAW campaign at the Swiss section. Her friends in arms qualified her as an "an important voice within the section" 243 who "had always been on the cutting edge" 244 and who "always tried to pick up [women's rights issues]." 245 According to one of her colleagues, the campaign coordinator was "[their] flagship that helped [them] a lot in [their] internal reflections" ${ }^{246}$ and "had been extremely well connected to a lot of women's organizations which helped her pus[h for] the development [of mainstreaming women's rights issues within the section]." ${ }^{247}$ Further, as a long-term official explained, the appointment of the campaign coordinator also improved the standing of the women's groups within the section: "[these women's groups] did certainly improve with the appointment of [the campaign coordinator] and there really was this integration with this networking. This was extremely important."248

Evidence indicates that the creation of the position of campaign coordinator of the SVAW campaign was the result of months-long women's network lobbying. It began with the network's intention to submit a respective motion to the section's GA at the beginning of 2002 . In fact, at its first national meeting in February 2002, the network members decided to write "a motion for a remunerated position within the Swiss section for women's rights issues [...]." ${ }^{249}$ They would submit the latter to the following $\mathrm{GA}^{250}$ if the section's management had not agreed with their proposition prior to that. The archival documents reveal that the network finally dispensed with it, as the management approved the allocation of additional resources to the engagement of a

réaliser la campagne interne au sein de la Section suisse, ainsi que la campagne publique et intégrer à long terme cette problématique dans la Section suisse.".

243 Ganzfried: Interview with B.K., 16.05.2013.

244 Ganzfried: Interview with A.P., 24.06.2013.

245 Ganzfried: Interview with A.P., 24.06.2013.

246 Ganzfried: Interview with A.J., 09.03.2012: "notre cheval de bataille nous a beaucoup aidé dans notre réflexion interne.".

247 Ganzfried: Interview with A.J., 09.03.2012: "Stella était une personne quiétait extrêmement bien resautée avec beaucoup d'organisations féminines. Ce qui fait qu'elle a pu vraiment pousser en fait le développement.".

248 Ganzfried: Interview with A.J., 09.03.2012: "Elles ont certainement gagné dès le moment où il y a eu l'engagement de Stella et il y a eu vraiment cette intégration avec cette Vernetzung ; c'est ça qui est extrêmement importants." .

249 Bourquin: Journée nationale du réseau femmes de la Section Suisse, 02.02.2002, p.5.

250 By submitting motions or postulates to the GA, the groups can shape the section's agenda. 
SVAW campaign coordinator. Instead, the network submitted a postulate to the $2003 \mathrm{GA}$, asking the EC and the ED to pursue the allocation of the necessary financial and personnel resources allowing women's rights issues to become a central and transversal theme in the section's overall work beyond the SVAW campaign. ${ }^{251}$ The postulate was unanimously accepted at the $2003 \mathrm{GA}$. It can be considered the basis of the sustainable professionalization of the Swiss section's work on VAW.

In addition to the nomination of the campaign coordinator, the section's management also installed a SVAW Project Team, composed of the campaign coordinator, the ED, and representatives from different departments, ${ }^{252}$ as "an interdepartmental structure that discusses the strategies of the [SVAW campaign] and their implementation" ${ }^{253}$. As a steering board, it assisted in defining and implementing the campaign's strategic options and facilitated the dissemination of the decisions to all staff members. ${ }^{254}$ Except for the campaign coordinator, the project team members were not part of the women's network.

With the establishment of the position of campaign coordinator and the decision to allocate the necessary financial and personnel resources for the section's work on VAW beyond the SVAW campaign, the section professionalized its work on women's rights and violence against women and created the basis for a sustained institutionalization. In contrast to the international level, where female activists and officials at the IS lost their influence on the organization's work on VAW over the course of the SVAW campaign, the Swiss section allowed its women's network to remain important in the definition of the section's work on these topics.

In fact, at the end of the first campaign phase, fearing that said professionalization would weaken women's groups's importance, a group of female activists around the campaign coordinator complained of the lack of coordination in the women's groups' activities (except for those taking place in the frame of the SVAW campaign). They also disliked that "each group pursue its

251 Amnesty International: Delegiertenversammlung 2003, 12.04.2003.

252 Amnesty International: Campagne contre les Violences envers les femmes (VAW) Séance du 8 mai 2003, 08.05.2003.

253 Amnesty International: Campagne contre les violences envers les femmes Groupe de projet séance du 2 septembre 2003, 02.09.2003, p.1.

254 Bourquin: Préparation de la VAW-update/listing, 09.09.2003, p.1. 
own issues and sets its own priorities." 255 They formulated the need to let women's groups assume the leading role in the sustainable incorporation of women's rights into the Swiss section, "independently of the coming [...] activities in the frame of the SVAW campaign,"256 and formed a new Ko-Gruppe Women's Rights in 2006. From then on, this Ko-Gruppe (coordinated by the campaign coordinator) organized the women's network's annual meetings ${ }^{257}$ and served as a vessel for the planning and coordination of the section's activities related to women's rights in general and of the SVAW campaign activities in particular.

The meeting minutes of the Ko-Gruppe Women's Rights show that it coordinated the women's groups' activities throughout the second campaign phase, organized the annual network meetings, and played a pivotal role in further institutionalizing the section's work on women's rights. In fact, the group discussed the question of "continu[ing] with the women's rights work in the section" 258 beyond the SVAW campaign and elaborated the "Swiss Strategy Women's Rights and Gender Mainstreaming," 259 a document meant to ensure the sustainable and broad integration of women's rights into the section's activities after 2010. The formation of the Ko-Gruppe Women's Rights thus allowed the reintegration of the women's groups into the agenda-setting process of the section's work on women's rights. It indicates that female activists and officials continued to influence the section's work on issues of VAW, even in the frame of the SVAW campaign.

Summing up, the previous sesction has illustrated the Swiss section leadership's commitment to the SVAW campaign. Meanwhile, the preceding paragraphs have highlighted the remaining importance of the section's women's network for the work on violence against women. It has further demonstrated that the Swiss section succeeded in professionalizing its work on VAW over

255 Amnesty International: Ko-Gruppe Frauenrechte Vorschlag für eine Neuorganisation und Umfrage zum Frauenrechts-Netzwerk, End of 2005, p.1: "Jede Gruppe verfolgt mehr oder weniger ihre eigenen Themen und setzt ihre eigenen Schwerpunkte.".

256 Amnesty International: Ko-Gruppe Frauenrechte Vorschlag für eine Neuorganisation und Umfrage zum Frauenrechts-Netzwerk, End of 2005.

257 Amnesty International: Frauenrechts-Ko-Cruppe Sitzungsprotokoll vom 3. April 2007, 03.04.2007; Amnesty International: Ko-Gruppe Frauenrechte AICH: Protokoll Sitzung vom 3.3.2009, 03.03.2009.

258 Amnesty International: Protokoll Frauenrechts-Kogruppe, 14.12.2009, p.1.

259 Amnesty International: Ko_gruppe Frauenrechte Protokoll Sitzung vom 22. September 2010, 22.09.2010, p.1. 
the course of the SVAW campaign and managed to build a sustainable approach to it. The section has shown that even though the SVAW campaign was implemented from the top to the bottom, female activists and officials continued to successfully influence the section's work on VAW by reorganizing their network.

\subsubsection{Women's rights - confined to a story by women acting for women}

This section focuses on the Swiss section's participation in and reaction to the SVAW campaign as well as on the internal discussions about the elaboration of the abortion policy. I demonstrate that opposition to the SVAW campaign and to the adoption of a policy on abortion was isolated at the Swiss section. The section further shows that even though the Swiss activists participated massively in the SVAW campaign, their involvement was more pragmatic and less driven by an enthusiasm for the campaign. The work on VAW remained mainly promoted by the members of the women's network. My interviewees' answers to the question "AI is engaging in many different rights, what rights are you engaging in?" also indicate that rather than mainstreamed among all members, VAW continued to be an issue mainly embraced and pushed by the members of the women's network. In fact, while a majority of the interviewed activists mentioned rights which are part of the Covenant on Civil and Political rights and two out of nineteen referred to economic, social, and cultural rights; no interviewed activist cited women's rights or issues of VAW as being in the center of his or her engagement at AI. This indicates that despite its management's commitment and its women's network's initiatives, the Swiss section did not succeed in making the issue of VAW part of its DNA. In fact, as I show hereafter, the conclusion of an internal evaluation of the Swiss section's capacity to engage in a women's rights campaign revealed that "women's rights remain[ed] confined to a story by women acting for women" ${ }^{260}$ at the end of the SVAW campaign.

Given the different roles that activists and officials play in the implementation of the SVAW campaign, the following paragraphs present these groups' participation and their reactions separately, beginning with the activists.

As part of the Gender Action Plan, activists were supposed to participate in workshops that sought to sensitize members to the issue of women's rights.

260 Amnesty International: Campagne interne (objectif stratégique 4 de la VAW), 09.09.2003, p.3. 
Evidence shows that despite the objective of reaching all members, only $20 \%$ of the Swiss AI groups - about a hundred activists, a majority of whom were women - participated in the workshops. ${ }^{261}$ Thus, an internal evaluation revealed that the "sensitization to gender issues of all activists of the Swiss section had not been realized via these workshops." ${ }^{262}$ Evidence suggests various reasons for the limited success of these training courses. First, the secretariat allocated insufficient resources for their implementation. According to an internal evaluation, workshops lacked timely and financial resources within the secretariat. ${ }^{263}$ Second, activists were not interested or did not have time. ${ }^{264}$ Another activist explained: "as a grassroots member who is working [...] then we are going to the workshops and then we cannot implement [what we learnt at the workshop] because we already used the time we can devote to AI." ${ }^{265}$ In another case, an activist declared: "I just do not have the time to participate in any workshop. [...] Besides, I do not think I need any more input on these topics." ${ }^{266}$ And third was the somewhat obligatory nature of the workshops. According to the workshop animator and campaign coordinator, "the contradiction between the 'quasi obligatory' nature of the animation proposed to the groups and the personal attachment necessary to accept to enter the relevant exercises" ${ }^{267}$ made activists abstain from participating. The workshop leader further explained that because the members overwhelmingly perceived

261 Amnesty International: Gender Action Plan: Auswertung mit Bettina Kurz und Philippe Beck, 01.06.2005.

262 Amnesty International: Evaluation des ateliers genre de la Section suisse, 06.10.2005, p.1: "La sensibilisation aux questions de gendre de l'ensemble des militant-e-s de la Section n'a pas été réalisé via ces ateliers genre.".

263 Amnesty International: Evaluation des ateliers genre de la Section suisse, 06.10.2005.

264 Amnesty International: Evaluation des ateliers genre de la Section suisse, 06.10.2005.

265 Ganzfried: Interview with A.U., 10.10.2012: "dass wir als Basismitglieder eben die schon arbeiten, nicht noch Zeit haben, also dann gehen wir in den Workshop und dann können wir es nicht umsetzen, weil wir nämlich die Zeit die wir für Al zur Verfügung haben schon gebraucht haben.".

266 Ganzfried: Interview with B.M., 12.10.2012: "ich habe schlicht keine Zeit um noch Workshops zumachen. keine chance und ob es die anderen gemacht haben vermutlich auch nicht also bei uns geht es allen ähnlich. insofern un dich habe auch nicht das gefühl ich müsste da noch gross input haben also das kommt noch dazu.".

267 C.: Email from C.A. to Stella Jegher concerning the gender workshops at AICH, 03.06.2004, p.1: "dans la contradiction entre le caractère 'quasi obligatoire' de l'animation proposée aux groups, et la nécessité d'une adhésion personnelle pour accepter d'entrer dans des exercices pertinents à ce sujet.". 
the Gender Action Plan, and therefore also the training courses, as an imposition by the IS, the plan severely challenged the groups' essential aspiration to engage anonymously, ${ }^{268}$ therefore hampering the workshops' success. According to the campaign coordinator, the workshops' failure had to do with the groups themselves, which "were not ready for such a project," ${ }^{269}$ and with those responsible for the preparation of the project, who "overlooked" 270 the membership's needs and opinions.

In contrast, the activists' participation in the public SVAW campaign activities was comparatively good. In fact, in addition to the women's groups, all sorts of groups actively took part in the campaign activities during its first two years. ${ }^{271}$ After the launch of the campaign in 2004, the campaign coordinator expressed her satisfaction in an internal memo: "the groups' participation was great, stands and actions in almost twenty cities!"272 In April 2005, she explained that "practically all active groups participated in the SVAW campaign." 273 However, in an interview, she qualified that "[the SVAW campaign] was positively received by the groups, but without provoking frenetic activism." ${ }^{274}$ In fact, as the interviews with activists also indicate, the groups' participation in the SVAW campaign was rather pragmatic. Referring to the campaign action "mobile home against domestic violence," an activist explained:

"Well, when a big campaign is coming from the secretariat and it is taking place in Berne, then they [the secretariat] most often rely on the resources of the Bernese groups [...], they [the Bernese groups] participate, that is evi-

C.: Email from C.A. to Stella Jegher concerning the gender workshops at AICH, 03.06.2004. Amnesty International: Gender Action Plan: Auswertung mit Bettina Kurz und Philippe Beck, 01.06.2005, p.1.

Amnesty International: Gender Action Plan: Auswertung mit Bettina Kurz und Philippe Beck, 01.06.2005, p.1.

7 Amnesty International: SVAW - Auswertung der Kampagne, 14.02.2005; Jegher: Motion 5a, Assemblée des délégué-e-s 2004 à Bienne, 26.04.2005; Jegher: Memo about the launch of the SVAW-campaign at the Swiss section, 2004; Amnesty International: Notice from Stella Jegher to Caroline Huwiler on the SVAW updates, 06.08.2004.

Jegher: Memo about the launch of the SVAW-campaign at the Swiss section, 2004, p.1.

Jegher: Motion 5a, Assemblée des délégué-e-s 2004 à Bienne, 26.04.2005, p.2.

Ganzfried: Interview with A.I., 26.09.2012: "je dirais que c'était positivement reçu par les groupes mais sans provoquer un activisme frénetique.". 
dent, if a campaign has been plonked in front of us, then we do not have to produce something just like that." ${ }^{275}$

Alluding to the same campaign action, another long-term activist described his group's participation as follows: "We integrated it into the annual actions [...]. But it has not been a permanent topic for our group." 276

While the activists generally welcomed the public SVAW campaign, evidence points to isolated cases of poor understanding related the campaign's focus and other cases of opposition to participation in the campaign due to its focus on domestic violence. In fact, some activists had problems with the practical implementation of the campaign because of the novelty of its issue. According to an interviewee, "there was a real interrogation about our capacity to act on violence against women." 277 As he explained, activists asked: "do I have to go to my neighbor who is beating his wife to tell him to stop?"'278 Additionally, activists from one particular professional AI group opposed a thematic campaign on VAW. An official explained: "extreme tensions occurred in the [former] medical group. Because it was about domestic violence and some men cancelled their membership in consequence." ${ }^{279}$ These members complained that the SVAW campaign was a feminist campaign, which ignored the universal principle of human rights. In a letter sent to the secretariat, an activist of the medical group disapproved of the focus on domestic violence stating: "Saying that women are victims of violence everywhere on the globe just because they are women is not true."280

275 Ganzfried: Interview with A.U., 10.10.2012: "also, wenn vom Sekretariat eine grosse Kampagne kommt und die in Bern ist, dann greifen sie meistens aufdie Ressourcen der Berner Cruppen zurück. [...] Die machen damit, das ist eigentlich klar. Wenn uns schon eine Kampagne vor die Nase gestellt wird, dann müssen wir nicht selber etwas aus dem Ärmel schütteln.".

276 Ganzfried: Interview with B. L., 24.06.2013: "wir haben es mehr integriert in die Jahresaktionen [...] Aber es ist nicht ein Dauerthema gewesen für unsere Cruppe.."

277 Ganzfried: Interview with A.I., 26.09.2012: "Il y avait une vraie interrogation concernant notre capacité d'agir par rapport à la violence à l'égard des femmes?".

278 Ganzfried: Interview with A.I., 26.09.2012: "Est-ce que je dois aller chez mon voisin qui bat sa femme pour lui dire d'arrêter?".

279 Ganzfried: Interview with A.K., 01.07.2013: "In den Medizinergruppen hat es EXTREME Spannungen gegeben. Weil da ist es natürlich wirklich auch um häusliche Gewalt gegangen und da hat es auch Kündigungen gegeben von gewissen Männern.".

280 C.: Letter addressed to Stella Jegher, 02.06.2004, p.1: "Dire que les femmes sont victimes de violence partout dans le monde du seul fait qu'elles sont des femmes n'est pas vrai.". 
The officials' reactions to the internal and to the public SVAW campaigns were quite different. In an e-mail, an official declared "personally regret[ting] the resources allocated to the GAP workshops for the groups."281 For another official, the campaign helped her focus more on women in her domain of work: "the fact that women's rights issues became transversal led to the prioritizing of women cases in the asylum domain, as well. ${ }^{282}$ According to another, the campaign affected his own work little. ${ }^{283}$ One official explained that "as everybody, [he] was supposed to put a women's rights component into [his] work, which sometimes became absurd,"284 and criticized the mainstreaming approach inherent to the campaign saying:

"[...] I am doing my annual planning for example, the parliamentary lobbying, and I am doing this depending on what? Depending on what I know, more or less, what will happen in the Parliament during the year. And then [the campaign coordinator] tells me 'ah and there is no women's action in there?', and I am telling her 'of course not, wait it is not me who is fixing the program of the Parliament'. [...] here I have certain resistance."285

Thus, evidence suggests that some officials seemed to find integrating VAWrelated issues into their work rather problematic. In fact, according to the same interviewee, there was no problem with the campaign itself, "as long as it remained in the domain of the campaign and the associated actions [...] it was not a problem for anybody, not me in any case." ${ }^{286}$ For another staff

281 C.: Email from W.G. to Stella Jegher concerning the gender workshops, 08.07.2004, p.3: "je regrette à titre personnel les ressources dévolues aux ateliers GAP auprès des groupes.".

282 Ganzfried: Interview with A.K., 01.07.2013: "also dass einfach die Frauenthemen ein Querschnittthema geworden ist, oder, hat dazu geführt dass wir einfach auch im Asylbereich sicher auch noch Frauendossiers Priorität eingeräumt haben.".

283 Ganzfried: Interview with A.H., 31.05.2013.

284 Ganzfried: Interview with A.A., 31.05.2013: "j'étais tenu comme tout le monde...des fois même jusqu'à l'absurde, de chaque fois mettre une composant Women's rights dans mon boulot.".

285 Ganzfried: Interview with A.A., 31.05.2013: "[...] je fais mon planning de l'année par exemple pour le lobbying parlementaire et puis je le fais en fonction de quoi? En fonction de ce que je sais, à peu près, qui va se passer au Parlement dans l'année. Et puis Stella me dit 'ah et alors il n'y a pas d'action femme là-dedans?', je lui dis 'non mais attends, ce n'est pas moi qui fixe le programme du Parlement.' [...], c'est là que moi j'ai quelques résistances.".

286 Ganzfried: Interview with A.A., 31.05.2013: "il n'y a pas eu de problème. Sur la campagne ellemême, tant que c'était dans le domaine de la campagne et des actions liées à la campagne [...] ça ne posait de problème à personne, en tout cas pas à moi.". 
member, the large spectrum of the topics covered by the campaign was problematic. He stated: "for a long time, we thought it was difficult to define what exactly we pick up because it was just somehow large and undefined [...]."287 An official emphasized the difficulties of working with the themes that the campaign proposed when it came to fundraising. He explained: "as long as you could work with violent pictures, such as acid attacks, it worked. But if afterwards you wanted to combine it with domestic violence in Switzerland, then it became increasingly difficult." ${ }^{288}$

Summing up, the Swiss section's activists generally welcomed the SVAW campaign and participated in most of the campaign activities, at least during the latter's first two years. Although most of the groups took part in the public campaign, evidence indicates that this participation was mostly pragmatic and not necessarily driven by the activists' enthusiasm for the campaign's thematic focus. Meanwhile, evidence suggests that parts of the staff did not oppose the implementation of the SVAW campaign but did show a certain reluctance to the focus of the campaign and sometimes had difficulties integrating issues of VAW into their respective fields of work. However, the SVAW campaign did not provoke activists' resistance, except in the case of a single group. The organization's work on VAW remained overwhelmingly in the hands of the women's network. Meanwhile, activists' and staff members' reaction to and participation in the SVAW campaign confirmed that the conclusion of a 2003 internal evaluation that "women's rights remained confined to a story by women for women," ${ }^{289}$ persisted after the end of the SVAW campaign.

Even though the Swiss section supported the elaboration of an abortion policy at the international level, the minutes of the 2005 and 2006 GA meetings suggest that internal debates on the topic took place at the Swiss section as well. In fact, at the $2005 \mathrm{GA}$, representatives from the EC, the International Commission, and the ED discussed the issue of sexual and reproductive rights

287 Ganzfried: Interview with A.F., 05.06.2013: "lange haben wir es schwierig gefunden, was nehmen wirjetzt genau aufund so, weil einfach [...] Irgend wo war es so breit und so undefiniert $[\ldots] "$.

288 Ganzfried: Interview with A.H., 31.05.2013: "solange du mit heftigen Bildern, eben wie die Säure-Attacken arbeiten konntest, hat es funktioniert. Sobald du es dann nachher kombinieren wolltest mit häuslicher Gewalt in der Schweiz, dann ist es schon schwieriger geworden.".

289 Amnesty International: Campagne interne (objectifstratégique 4 de la VAW), 09.09.2003, p.3. 
in one of the thematic forums. ${ }^{290}$ The participants there agreed to support the option that called upon the IEC to elaborate a policy on the non-controversial issues of abortion. Activists and officials seemed to have been more divided when they had to decide upon the content of the respective policy a year later. At the $2006 \mathrm{GA}$, following the IEC proposition, the EC offered the section the chance to position itself on the three aspects of abortion. ${ }^{291}$ At the same time, a local group submitted a motion refusing to take any position. ${ }^{292}$ During the vote in plenary, the participants very clearly rejected the local group's proposition with 98 against 27 votes and adopted the EC position with 87 against 17 votes. $^{293}$

The minutes of the 2006 meeting of the GA show the activists' disagreement on the issue of abortion. The local group officially explained its position with the fear that $\mathrm{AI}$ would lose its focus and become increasingly fragmented "by focusing on 'sexual and reproductive' rights, beside the newly defined strategy of working on economic, social, and cultural rights. ${ }^{294}$ Further, the local group explained that: "The members of the group [xy] consider that the right to life begins at the moment of conception; we do thus not understand how AI could argue in favor of abortion. Abortion has to be considered as infanticide." 295

The controversial nature of abortion also became evident when some of the long-term activists dropped out. One of my interviewees revealed that those who left AI when the organization adopted its policy on abortion, were

290 Amnesty International: Delegiertenversammlung 2005, 29.05.2005, p.10.

291 Decriminalization of abortion; access to quality services for management of complications arising from abortion; and access to legal, safe, and accessible abortion in the case of an unwanted pregnancy (Amnesty International: Postulat A Position der Schweizer Sektion zu Abtreibung, Delegiertenversammlung 2006, 07.05.2006).

292 Amnesty International: Motion 9 Stellungnahme der Sektion zum Thema Abtreibung Delegiertenversammlung 2006, 07.05.2006.

293 Amnesty International: Protokoll der Delegierteversammlung 2006 in Delémont, 07.05.2006.

294 Amnesty International: Motion 9 Stellungnahme der Sektion zum Thema Abtreibung Delegiertenversammlung 2006, 07.05.2006, p.1.

295 Amnesty International: Protokoll der Delegierteversammlung 2006 in Delémont, 07.05.2006, p.14: "Die Mitglieder der Regionalgruppe [xy] sind der Ansicht, dass das Leben bereits mit der Empfängnis beginnt; demnach verstehen wir nicht, wie Al sich zugunsten der Abtreibung aussprechen kann. Abtreibung muss als das gesehen werde, was es ist: Kindsmord.". 
people from religious communities. The official explained: "we were confronted with resistance even at the level of the Swiss section. We had people from religious communities who had been very engaged for many years, who left AI because they could not identify any more with [this new agenda]."296 Other activists did not leave AI or "resist the work on reproductive rights but" preferred "not to engage in this matter."297

Thus, at the Swiss section, opposition against the adoption of an abortion policy existed but was rather isolated. Evidence suggests that, resistance also mainly came from conservative church-related activists or groups, similar to what was observed at the international level.

Consequently, the Swiss section's success in integrating VAW into its overall work can be summarized as follows. First, the Swiss section successfully merged the section's priorities on the issues of VAW with the international campaign strategy. The section adopted the thematic focus of the general campaign and emphasized domestic violence as a national human rights concern for the first time. At the same time, the section conducted an internal campaign to sensitize its members and staff to gender equality. Second, the section professionalized its work on VAW in the long term by creating the position of a campaign coordinator within the secretariat and ensuring its funding beyond the SVAW campaign. Third, the section's leadership seems to have committed to the SVAW campaign. Fourth, the Swiss section's women's network continued to influence the section's work on VAW, even in the frame of the SVAW campaign being implemented from the top down. Fifth, while officials harbored certain skepticism towards the campaign, the SVAW campaign did not generally provoke Swiss activists' and officials' resistance. Further, opposition against the adoption of an abortion policy was isolated at the Swiss section.

296 Ganzfried: Interview with A.J., 09.03.2012: "On a eu droit à des résistances même au niveau de la section suisse d'Al. On avait des gens qui était des communautées réligieuses très engagées depuis des années qui ont quitté Al parce qu'ils n'arrivaient plus à se retrouver dans [cette nouvelle agenda].".

297 Ganzfried: Interview with B.K., 16.05.2013: "Nein, zu diesen reproduktiven Rechten nicht Widerstand aber so im Sinn von "ch möchte mich lieber nicht zu dem engagieren". 


\subsubsection{The German section}

The present chapter shows how the German section implemented the SVAW campaign and demonstrates that the section did not succeed in integrating issues of VAW into the section's overall work through the SVAW campaign. First, the chapter focuses on the thematic content of the German section's SVAW campaign named Look \& Act: Preventing violence against women. ${ }^{298}$ It shows that this campaign strongly emphasized AI's traditional women's rights issues, such as female human rights defenders and FGM, and did not address the general campaign's central concern - "domestic violence" as a national human rights issue. Then I demonstrate that the MaF played a pivotal role in the implementation of the Look $\mathcal{E}$ Act: Preventing Violence against Women campaign, and it no longer tried to influence decision-making at the national or the international level. Meanwhile, the personnel resources allocated to the work on VAW at the secretariat continued to be relatively low. Finally, I emphasize the membership's particularly critical stance towards the campaign, and highlights the existence of important resistance to it and significant opposition to the adoption of a policy on abortion.

\subsubsection{Look \& Act: Preventing Violence against Women}

Diverging from the overall campaign, the German section labeled the SVAW campaign Look \& Act: Preventing Violence against Women. The German section organized an internal and a public campaign, implementing the SVAW campaign as a priority campaign between 2004 and 2005 . Evidence shows that the German section did not implement the second campaign strategy. Instead, issues of VAW were discussed as "one of the main AI issues in the 'regular' country and thematic work," country groups continued with campaign activities after $2005 .{ }^{300}$ Based on the internal gender audit carried out in 2002 , the section formulated an internal campaign objective meant to "ancho[r] equal opportunities at all levels

\footnotetext{
298 Hinsehen \& Handeln: Gewalt gegen Frauen verhindern.

299 Amnesty International Sektion Bundesrepublik Deutschland: Ausformulierte Auswertung SVAW - Campaign, no date, p.1.

300 When talking about the contents and the activities of the campaign, I thus mainly concentrate on the period between 2004 and 2006. I was not able to access archival material on the groups' activities, as these documents are overwhelmingly kept by the different groups themselves.
} 
of AI." ${ }^{301}$ According to a former member of the EC, the internal campaign was implemented mainly before the public campaign. The women's group organized workshops about the SVAW campaign and specifically on the issue of sexual and reproductive rights as part of the former. ${ }^{302}$

The German section's public campaign focused on "VAW in armed conflicts" and "domestic violence," yet placed special emphasis on traditional human rights issues, such as "the support of women human rights defenders," and primarily addressed family violence if it occurred in other countries. ${ }^{303}$ A member of the MaF emphasized the importance of focusing on women human rights defenders at the German section: "How difficult it may be for women, there are always [...] courageous women who are engaging against violations of human rights in their country [...] and to support them, that is of big importance to AI [...]." 304 The section mainly focused on cases of VAW in other countries, such as murders of women in Ciudad Juarez, Mexico, women trafficking and forced prostitution in Kosovo, family violence in Turkey or the consequence of local tribe courts in Pakistan. ${ }^{305}$ Thus, even in the frame of the SVAW campaign, the German section continued to emphasize issues of VAW, which had already been the focus of the organization in the 1990s.

This traditional focus was also reflected in groups' activities. As written in the ai intern, the journal for the German section's members, several groups organized expositions in 2005 . The latter aimed at "giving visitors an understanding of the reality of fleeing, scared, abused and disfigured women from almost all continents and [pointed] to the urgency of the omnipresent violence especially against women." ${ }^{306}$ An interviewee explained the continuing

301 Amnesty International Sektion Bundesrepublik Deutschland: Zwischenbilanz der Kampagne "HINSEHEN \& HANDELN: Cewalt gegen Frauen verhindern", 02.11.2005, p.1: "Cleichberechtigung auf allen Ebenen innerhalb von amnesty verankern.".

302 Ganzfried: Interview by Skype with A.C., 26.04.2015.

303 Amnesty International Sektion Bundesrepublik Deutschland: Zwischenbilanz der Kampagne "HINSEHEN \& HANDELN: Cewalt gegen Frauen verhindern", 02.11.2005.

304 Ganzfried: Interview by phone with A.Y., 09.01.2015: "wie schlimmes auch immer für Frauen stehen möge, es gibt immer [...] mutige Frauen, und beherzte Frauen, die sich einsetzen gegen die Menschrechtsverletzungen in ihrem Land [...] und die zu unterstützen, das ist ein grosses Anliegen von Al [...].".

305 Amnesty International Sektion Bundesrepublik Deutschland: Zwischenbilanz der Kampagne "HINSEHEN \& HANDELN: Cewalt gegen Frauen verhindern", 02.11.2005.

306 Amnesty International Sektion Bundesrepublik Deutschland: ai intern Rundbrief für Mitglieder der deutschen Sektion von amnesty international, September 2006, p.10: "Besuchern die Realität von fliehenden, verängstigten, misshandelten und entstellten Frauen von 
importance that the traditional approach to VAW held for the German section: "The closer it comes to our country, the more difficult it becomes. [The German section] did not actually work on Germany."307

As far as concrete activities were concerned, except for the MaF, local and country groups participated in the campaign and often organized their VAW actions on the occasion of the international women's day or the " 16 days against VAW."308 After 2005, women's rights continued to be mainly thematized within the frame of the section's work on refugee and asylum issues. For example, the section lobbied government institutions to grant refugee status to women facing FGM in their home lands and participated in a campaign against forced prostitution in Germany. It also called attention to the problem of sexual abuse and exploitation of au-pair girls and women. ${ }^{309}$

In contrast, AI members expressed their support for engaging against other forms of violence against women, particularly female genital mutilation. The minutes of the meetings of various general assemblies show that $\mathrm{AI}$ members repeatedly called upon the section to increase its work on FGM. In 2007, the GA called on the EC to examine how to strengthen the work on FGM in consultation with the IS. ${ }^{310}$ In 2008 , the GA asked the EC to demand that AI increase its work on FGM. ${ }^{311}$ The section's participation in a national network on FGM a year later testifies to the importance of this specific women's rights issue for the German section. ${ }^{312}$ An interviewee explained the emphasis on FGM as follows: "[FGM] is a cruel human rights violations that happens

fast allen Erdteilen näher zu bringen und auf die Dringlichkeit der allgegenwärtigen Cewalt besonders gegen Frauen hinzuweisen.".

307 Ganzfried: Interview with A.C., 14.04.2015: "Also je näher es unserem Land / unserer Gesellschaft kommt, desto schwieriger wird es auch. Also zu Deutschland [hat die Deutsche Section] eigentlich nicht gearbeitet."

308 Amnesty International Sektion Bundesrepublik Deutschland: Grobe Auswertung des Fragebogens zu der Kampagne Hinsehen \& Handeln, ca. 2006.

309 Amnesty International, International Secretariat: Feedback and updates from sections and structures on their SVAW related work carried out at national level, July 2008, p.4-5.

310 Amnesty International Sektion Bundesrepublik Deutschland: Beschlüsse der 42. Jahresversammlung 2007 in München, 2007.

311 Amnesty International Sektion Bundesrepublik Deutschland: Beschlüsse der 43. Jahresversammlung 2008 in Hamburg, 2008.

312 Amnesty International Sektion Bundesrepublik Deutschland: Amnesty Intern Zeitschrift für Mitglieder von Amnesty International, March 2009. 
far away." 313 The interviewee continued stating: "In fact, it would have certainly been most comfortable for AI if the issue of women's rights had been reduced to FGM. Because this is ok. The German section has always been engaged in this issue and this has always been important for them. But beyond, it is clearly more difficult." 314

The previous paragraph has shown that even within the frame of the SVAW campaign, the German section continued to mainly emphasize AI's traditional issues of VAW, such as women human rights defenders, FGM, and cases of VAW in other countries. Yet, it only marginally addressed the problem of domestic violence in Germany.

\subsubsection{The MaF - a group of voluntary experts}

As chapter 7.2.2 explained, the women's rights group MaF pushed the section's work on women's rights throughout the 1990s and was also responsible for many of the strides that were made in this issue area. In the same decade, without having specific terms of reference, the official responsible for refugee and asylum issues integrated VAW into her daily work. Thus, no staff member was uniquely responsible for women's rights issues when the organization decided to center its first global thematic campaign on VAW. The present section demonstrates that this distribution of roles with respect to the work on VAW barely changed with the preparation and the implementation of the SVAW campaign. ${ }^{315}$ After the dissolution of the first MaF at the end of the 1990s, a new women's rights group, which was also called MaF, was founded at the beginning of the 2000s. While this group continued carrying out the majority of the work on women's rights issues, the human resources allocated to work on VAW, and specifically to the implementation of the SVAW campaign, at the secretariat continued to be limited.

313 Canzfried: Interview with B.T., 15.04.2015: "Das ist eine grausame Menschenrechtsverletzung und weit weg."

314 Ganzfried: Interview with B.T., 15.04.2015: "Also für Amnesty Deutschland wäre es sicherlich am angenehmsten gewesen, wenn das Thema Frauenrechte aufdas Thema Cenitalverstümmlung reduziert worden wäre. Weil das ist völlig d'accord, ja? Also da hat die deutsche Sektion sich immer dafür stark gemacht und das war ihnen auch immer wichtig, aber darüber hinaus ist es deutlich schwieriger.".

315 In contrast to the Swiss section, for which I found abundant archival material, archival documents on the existing organizational structures responsible for the work on VAW at the German section were scarce. The following findings are thus mainly based on interview testimonies. 
Evidence shows that the SVAW campaign was prepared by a steering group, composed of "relevant Section staff and one member of the women's group," 316 and implemented by the MaF and two staff members. In fact, just like in the 1990s, the MaF shared the thematic responsibility for the campaign with an official who was based in the Countries and Asylum department. ${ }^{317}$ The latter was only able to spend 3 and, later, 9 hours per week on VAW issues. $^{318}$ Additionally, a campaigner who was already working on other campaigns assumed the coordination and the communication of SVAW. ${ }^{319}$ However, this campaigner was only available during the initiative's first two years. From 2006 onward, the MaF and some country groups were the only ones who continued the campaign activities. ${ }^{320}$

The MaF's continued importance for the section's work on VAW also becomes evident when we consider the section's contact with the media on the SVAW campaign. An interviewee explained: "if [the media requests] concerned women's issues, then they were usually passed on to [the MaF], [...], the [expert on women's rights at the secretariat] did not give any interviews." ${ }^{321}$ It is thus not surprising that officials considered the members of the MaF "voluntary experts," ${ }^{322}$ rather than simple activists. As the following statement reveals, MaF members viewed their group as pivotal for the section's work on VAW during the SVAW campaign as well: "well, one may say that my group

316 Stop VAW campaign team: STOP VAW Campaign Progress update 4, 12.2003, p.2.

317 Afrika Referentin in der Abteilung Länder und Asyl. Amnesty International Sektion Bundesrepublik Deutschland: ai intern Rundbrieffür Mitglieder der deutschen Sektion von amnesty international, April 2007.

318 Ganzfried: Interview by phone with A.Y., 09.01.2015; Ganzfried: Interview with B.T., 15.04.2015.

319 The campaigner explained her job as follows: "Well we [were] also doing centralized measures, promotion, events or so [...]. Our jobs actually [consisted] in enabling the members to do effective local campaigning, providing them with good material, good arguments, Q\&A's, all this kind of stuff, you know. Because we only have a limited range." Or, as explained by a women's group member, the officials "produced the material; material means leaflets, postcards, flyers, buttons, eventually and posters and so on, [...].".

320 Ganzfried: Interview by phone with A.Y., 09.01.2015: "Ab 2006 haben wir es dann allein gemacht mit den entsprechenden Länder-Ko-Gruppen und da haben wir noch ganz viel gemacht und manche Länder-Ko-Gruppen haben auch das allein gemacht [...].".

321 Ganzfried: Interview by phone with A.Y., 09.01.2015: "Wenn es Frauenthemen sind, werden die meisten an uns weitergeleitet, also so gut wie immer. Also [die Expertin im Sekretariat] hat überhaupt keine Interviews gegeben." Ganzfried: Interview with B.T., 15.04.2015. 
was an important push factor for the whole women's work. [...] If we had not been here, I do not know, [...]. We are quite essential to the section's work on the issue of women. That is a fact." ${ }^{23}$ The MaF thus continued to play a pivotal role in the section's work on VAW throughout the 2000 , also because the overall organization of the German section meant that the thematic groups remained important for the section's thematic work.

However, in contrast to the 1990s, when the MaF pushed the organization to increase its work on VAW and women's rights both internally and at the international level, the German women's group no longer remained a relevant internal actor in the 2000 s. For example, the MaF did not try to influence decision-making at the national or the international level any more. This distinguishes the MaF from its Swiss counterpart, which successfully pushed for professionalizing the work on VAW by submitting its demand to the GA (the demand was accepted). Thus, it is worth assuming that the female activists and officials who pushed the work on VAW in the 1990s lost their influence in defining the section's work on VAW in the 2000s.

At the same time, evidence also shows the ED's commitment to women's rights issues in general and to the SVAW campaign in particular. Several interviewees referred to Barbara Lochbihler as particularly committed to and very progressive towards women's rights. ${ }^{324}$ One interviewee explained that the section's participation in the SVAW campaign and especially the favorable allocation of resources at the secretariat happened thanks to Barbara Lochbihler, who considered AI's engagement against VAW a part of the larger

323 Ganzfried: Interview by phone with A.Y., 09.01.2015: "Also man kann schon sagen, dass meine Gruppe ein wesentlicher Push-faktor ist für die ganze Frauenarbeit. [...] wenn wir nicht da wären, wüsste ich nicht, [...]. Wir sind schon sehr wesentlich für die Arbeit zum Thema Frauen der Sektion, das ist klar.".

324 Ganzfried: Interview by phone with A.Y., 09.01.2015; Ganzfried: Interview with A.C., 14.04.2015; Ganzfried: Interview with B.T., 15.04.2015; Ganzfried: Interview by phone with A.Q., 27.02.2015. 
work on human rights. ${ }^{325}$ In contrast, as I demonstrate later, the EC was less convinced by the SVAW campaign.

\subsubsection{Highly controversial issues - domestic violence and abortion}

By focusing on the participation in and the reactions to the SVAW campaign and on the internal discussions surrounding the elaboration of AI's abortion policy, the present section sheds light on the important and widespread opposition to the work on issues of VAW at the German section. In contrast to what we observed at the international level, where the opposition to the SVAW campaign was motivated by a general criticism of the adoption of the mission or where resistance related to the structure and the setting of the campaign, the German section mainly resisted the campaign's content. However, this does not mean that the section did not oppose the campaign for other reasons, as well.

My findings do not allow me to discuss how many of the local AI groups effectively participated in Look \&Act: Preventing Violence against Women. Nevertheless, evidence shows that approximately two thirds of the German AI groups signed up for the campaign, ${ }^{326}$ although only a few local groups continued to take part in campaign activities during the second phase. A September 2005 evaluation of the campaign reveals that "experienced group spoke persons report[ed] back that it [would] be extremely difficult to motivate members for the campaign any longer." 327 At the same time, the German section's membership had to be convinced to work on issues of VAW as portrayed in the SVAW campaign. An interviewee explains that members argued that women's

325 Ganzfried: Interview with B.T., 15.04.2015: "Unsere damalige Ceneralsekretärin Barbara Lochbihler, [...] der war das Thema eben auch sehr wichtig. [...] Insofern hat das natürlich [...] schon auch immer dazu geführt, dass sich die Sektion da jetzt auch nicht so völlig [...] da raushalten konnten zum Thema. [...] ich denke das [...] dass Barbara damals das als wichtigen Aspekt der Menschenrechtsarbeit eben auch gesehen hat, das [...] hat eben auch dazu beigetragen, [...] dass hauptamtlich zumindest irgendwie immer mal ein paar Ressourcen dafür zur Verfügung gestellt wurden, ja so und dass das nicht nur rein ehrenamtlich wirklich bearbeitet wird.".

326 Amnesty International Sektion Bundesrepublik Deutschland: Protokoll der 40. Jahresversammlung 2005 in Leipzig, 2005, p.1: "Innerhalb der deutschen Sektion haben sich erfreulicherweise über 400 Gruppen für die Kampagne angemeldet.".

327 "Erfahrene GruppensprecherInnen melden zurück, dass es enorm schwierig wird, Mitglieder weiterhin für die Kampagne zu motivieren." Hartmetz: Hinsehen \& Handeln: Gewalt gegen Frauen verhindern, 02.09.2005, p.1. 
(rights) organizations were better placed to defend the rights of women and that "AI should better engage for the individual political prisoner." ${ }^{328}$ According to an official, for AI members "issues such as women's rights still feel somehow strange"329 and "had to actually find acceptance first." 330 The following statement further reveals that parts of the section did not take the issue of VAW and the work of the MaF seriously. In fact, an interviewee at one of the GAs reported that "[the women activists] had been portrayed as the lilac dungarees who somehow wanted AI to change and would likely make it disappear." 331

Moreover, some of the opposition to the SVAW campaign was radical. In fact, compared to the Swiss section, where opposition essentially came from one particular group, deep-seated resistance was prevalent among part of the membership of the German section. As the following excerpt from a letter from a member indicates, the opposition was based on the members' belief that domestic violence is not an issue of human rights: "[women victims of domestic violence] do not need the protection of a human rights organization, insofar as it is actually about private conflicts between free and adult human beings in a liberal, open society. Here AI is absolutely out of place [...]." ${ }^{332}$ Numerous protest letters reveal the members' harsh criticism of the SVAW campaign, accusing it of being partial, discriminatory or even racist towards men. The authors of these letters complained that the SVAW campaign discriminated against men and violated the universality of human rights. ${ }^{333}$ According to the writers, the campaign was ideologically biased and "an in-

328 Ganzfried: Interview with B.T., 15.04.2015: "Amnesty soll sich dann halt lieber für den einzelnen politischen Gefangenen einsetzen,".

329 Ganzfried: Interview with B.T., 15.04.2015: "so Themen wie Frauenrechte ist irgendwie, ja, es ist ihnen irgendwie immer noch fremd.".

330 Ganzfried: Interview by phone with A.Y., 09.01.2015: "das Thema Frauen überhaupt erst mal Akzeptanz finden müssen.".

331 Ganzfried:Interview by phone with A.Q., 27.02.2015: "wirirgendwie ein bisschen so als die, als die lila Latzhosen hingestellt worden sind, die jetzt irgendwie Amnesty so verändern wollen, dass es die Organisation wahrscheinlich bald nicht mehr gibt.".

332 C.: Protest letter to the German Al section, 14.04.2004, p.2: "[Frauen, Opfer von häuslicher Gewalt] benötigen aber nicht den Schutz einer Menschenrechtsorganisation, soweit es sich nämlich um private Konflikte von freien, erwachsenen Menschen in einer liberalen, offenen Cesellschaft handelt. Hier ist Al absolut Fehl am Platz [...]".

333 C.: Protest letter to the Cerman Al section, 26.05.2006; C.: Protest letter to the Cerman section, 19.04.2004; C.: Protest letter to the German Al section, 06.06.2004. 
strument of the gender war raging in Germany."334 Another author saw AI adopting "a feminist gender racism"335 and called upon the organization not to let itself be abused by the "ongoing feminist 'differentiating campaign."336

In their letters, the members often questioned the gendered prevalence of domestic violence asserting that in contrast to what the campaign communicated, domestic violence concerned men as much as women, if not more. ${ }^{337}$ In an open protest letter, the authors warned AI of a potential loss of members as a result of the "ideologically motivated" 338 campaign, which discriminated against men. The author polemically asked: "Are children and men less worthy of protection from violence?" 339 As the following statement reveals, some opponents must have also resigned from the organization as a consequence of the SVAW campaign: "You will understand, that I do not want to support an organization that criminalizes me because of my sex." 340

In addition to the members' criticism of the work on VAW, my findings also indicate that parts of the section's leadership were skeptical of the SVAW campaign. In fact, a former EC member explained: "We had resistance to, for example, the gender audit in the EC itself. I did not think it was good then, [...] especially because there were many women in the EC at that time." ${ }^{341}$ Pointing

334 C.: Protest letter to the German Al section, 29.03.2004, p.1; C.: Protest letter to the German AI section, 26.05.2006; Gemeinnütziger Bundesverein: Open protest letter to the German AI section, 06.05.2004; C.: Protest letter to the German section, 19.04.2004; C.: Protest letter to the German Al section, 14.04.2004.

335 C.S.: Protest letter to the German Al section, 15.03.2004, p.1: "feministischer Ceschlechterrassismus".

336 C.S.: Protest letter to the German Al section, 15.03.2004, p.1: "laufenden, feministischen 'Differenzierungskampagne".

337 C.S.: Protest letter to the German Al section, 29.03.2004; C.: Protest Letter to the German Al section, 11.05.2004; C.: Protest letter to the German Al section, 17.05.2004; C.S.: Protest letter to the German Al section, 15.03.2004.

338 Gemeinnütziger Bundesverein: Open protest letter to the German Al section, 06.05.2004, p.2: "ideologisch motiviert".

339 Gemeinnütziger Bundesverein: Open protest letter to the German Al section, 06.05.2004, p.3: "Sind Kinder und Männer es weniger wert, vor Gewalt geschützt zu werden?".

340 C.: Protest letter to the German Al section, 17.05.2004, p.2: "Sie werden verstehen, dass ich keine Organisation unterstützen möchte, die mich aufgrund meines Geschlechts kriminalisiert.".

341 Ganzfried: Interview by Skype with A.G., 26.04.2015: "Wir haben im Vorstand selber zum Beispiel den gender audit auch Widerstand gehabt, fand ich damals nicht so gut, [...] zumal in unserem Vorstand damals ziemlich viel Frauen waren. Wo ist denn das Problem?". 
to the appropriate representation of women in different positions all over the section, the interviewee stated: "insofar, the necessity [of conducting a gender audit] was not really seen." 342

Thus, generally speaking, the German section's membership was rather critical of the SVAW campaign and parts of the membership, mainly men, clearly opposed the campaign. Furthermore, there also was criticism of and resistance to the campaign from within the EC.

As mentioned in section 8.1.4, the German section was one of the few sections that firmly opposed the adoption of a policy on abortion and advocated for the status quo of a neutral position at the 2005 and the 2007 ICMs. Given that a section's official position at the ICM is generally preceded by a decision of the section's GA and that members ultimately exercise their decisionmaking power via their vote at the annual GAs, we can assume that the German section's position at the ICM reflected the opinion of a majority of the German AI members.

As the following paragraph reveals, the decisions of the German section's GAs on the adoption of the abortion policy reflects the restrictive opinion of the majority of the membership. It also demonstrates the importance that the section attached to maintaining a neutral position on abortion. In fact, at the 2006 GA, the members called "the Executive Committee, the ICM delegation, and the delegates of the German section to the Chairs Forum in June 2006 to pledge for the preservation of neutrality with regards to the right to abortion at all levels of the international organization." 343 A year later, at the 2007 GA, the members agreed on the contents of the section's resolution to the ICM ${ }^{344}$ and called the EC to anticipate the modification of the neutral position on abortion. The members called on the EC "to communicate as soon as possible the expectation of the members who do not share the new position," 345 and to express its opinion, "if AI members can not only have their own personal

342 Ganzfried: Interview by Skype with A.G., 26.04.2015: "insofern war die Notwendigkeit nicht so ganz gesehen worden.".

343 Amnesty International Sektion Bundesrepublik Deutschland: Beschlüsse der 41. Jahresversammlung 2006 in Berlin, 2006: "die ICM-Delegation und die Delegierten der Deutschen Sektion für das Chairs Forum im Juni 2006 auf, sich in allen Ebenen der internationalen Organisation für die Wahrung der Neutralität zur Frage des Rechts auf Abtreibung einzusetzen.".

344 Resolution HRS D.

345 Amnesty International Sektion Bundesrepublik Deutschland: Beschlüsse der 42. Jahresversammlung 2007 in München, 2007, p.6: "baldmöglichst eine Aussage darüber zu tr- 
opinion, but if they may express and declare it or if this will be considered as an attitude damaging for the association." ${ }^{346}$

After the adoption of the policy on selected aspects of abortion, the German section critically observed the rigorous application of the policy and its potential future modification. In fact, the $2008 \mathrm{GA}$ called on the EC and all other thematic bodies of the German section to "defend a restrictive position on abortion [...]. Further, the EC should, if need be, actively involve itself and specifically pledge for the respect of the highest possible transparency and democratic processes in case of any modification of the actual position." ${ }^{347}$ As explained by one of my interviewees, after the adoption of the AI policy on selected aspects of abortion, members continued to monitor the implementation of the policy as well as any potential future modifications: "quite a few members of our section pay attention very thoroughly that all petitions and announcements" ${ }^{348}$ respect the decision agreed upon at the 2007 ICM.

Similar to the international level, the members and staff at the German section subjected Al's abortion policy to substantial discussions. As the following testimony shows, the policy continued to be a subject of controversy until recently. An activist explained: "There is a really delicate issue in our section. [Abortion] is still triggering very, very huge resistance, even today."349 Referring to the discussion in the 2000s, an activist stated that some of her

effen und intern zu kommunizieren, wie die Erwartung an Mitglieder ist, die die neue Position nicht teilen.".

346 Amnesty International Sektion Bundesrepublik Deutschland: Beschlüsse der 42. Jahresversammlung 2007 in München, 2007, p.6: "Insbesondere wird er sich dazu äußern, ob ai-Mitglieder nicht nur ihre eigene abweichende persönliche Meinung haben können, sondern sie auch in ai-Zusammenhängen benennen und bekennen dürfen oder ob dies als vereinsschädliches Verhalten gewertet wird.".

347 Amnesty International Sektion Bundesrepublik Deutschland: Beschlüsse der 43. Jahresversammlung 2008 in Hamburg, 2008, p.4: "sich für eine restriktive, nur auf schwere Menschenrechtsverletzungen bezogene, und menschenrechtskonforme Position zum Schwangerschaftsabbruch, einzusetzen, sich gegebenenfalls aktiv einzubringen, und insbesondere aufdie Beachtung größtmöglicher Transparenz und demokratischer Prozesse bei jeglicher Änderung der derzeitigen Position zu drängen.."

348 Canzfried: Interview by phone with A.Y., 09.01.2015: "Es gibt in unserer Sektion etliche, also Mitglieder die das GANZ streng daraufachten, dass äh bei allen Verlautbarungen und Petitionen und was, das nicht anders rüberkommt.".

349 Ganzfried: Interview by phone with A.Y., 09.01.2015: "Es gibt ein ganz heikles Thema bei uns auch in der Sektion. Aus unserer Sektion gab es halt sehr sehr grosse Widerstände auch heute noch [dem Theam abortion gegenüber].". 
colleagues refused to work on the issue of abortion. According to her, the internal resistance was harsh and opponents predicted a "horror vision" 350 of a section that would fall apart if the organization decided to take a position on abortion.

The extent of the opposition becomes visible in an internal non-representative survey of German section activists, realized in 2006. The study showed that almost $74 \%$ of the activists either partially or entirely opposed an AI engagement on the issue of abortion. ${ }^{351}$ Numerous letters to the editors of the membership magazine ai intern ${ }^{352}$ show the vivacity and the content of the controversy. An activist explained his resistance thus: "I can already hardly bear that AI is engaging with a lot of energy against the Death Penalty and remaining silent on the issue of abortion. If AI ought to engage for the right to abortion.... I want to work for human rights and not against them!!!"353 Another AI member published his support for the adoption of an abortion policy by expressing his incomprehension of denying health services to women suffering from complications after an abortion stating: "all, dangerous criminals as well - the comparison is already hardly acceptable in my point of view have the right to access to medical treatment, if needed. A human rights organization should take this for granted." 354 Thus, abortion was and continued to be a highly controversial issue for the German AI section until recently. Resistance to AI adopting a position on abortion was widespread and very strong.

Consequently, the German section's success in integrating VAW into its work can be summarized as follows. First, in contrast to the overall cam-

350 Ganzfried: Interview by phone with A.Y., 09.01.2015: "Eine Horrorvision".

351 Amnesty International Sektion Bundesrepublik Deutschland: ai intern Rundbrief für Mitglieder der deutschen Sektion von amnesty international, June 2006, p.1.

352 Published between June 2006 and November 2007.

353 Amnesty International Sektion Bundesrepublik Deutschland: ai intern Rundbrief für Mitglieder der deutschen Sektion von amnesty international, June 2006, p.7: "Es ist für mich schon jetzt sehr schwer zu ertragen, dass sich Al mit viel Energie für die Abschaffung der Todesstrafe einsetzt, aber beim Thema Abtreibung schweigt. Falls sich Al für ein Recht auf Abtreibung einsetzen sollte, .... Ich möchte für die Menschenrechte arbeiten, und nicht dagegen!!!".

354 Amnesty International Sektion Bundesrepublik Deutschland: ai intern Rundbrief für Mitglieder der deutschen Sektion von amnesty international, September 2006, p.12: "Alle, auch Schwerverbrecher - der Vergleich ist hier meiner Auffassung nach bereits kaum akzeptabel - haben das Recht auf eine medizinische Versorgung, falls dies erforderlich ist. Für eine Menschenrechtsorganisation sollte dies selbstverständlich sein.". 
paign and to the Swiss section, the German section's Look $\&$ Act: Preventing Violence against Women essentially focused on AI's traditional women's rights issues, such as women human rights defenders and FGM. It did not address the campaign's central concern, namely "domestic violence" as a national human rights issue. Second, the German section's internal structures working on issues of VAW remained largely the same as in the 1990s. The human resources allocated to the work on women's rights at the secretariat never exceeded nine working hours a week, just like in the 1990s. Thus, in contrast to the Swiss section, there was no professionalization of the section's work on VAW. Third, we lack information on the German section's leadership's commitment to the SVAW campaign. Fourth, the data indicate that the influence of the MaF on the section's work on VAW in the 2000 s was less important than it had been in the previous decade. In fact, while the MaF continued to operate as the section's expert group on all issues related to VAW, it no longer tried to influence decision-making on the matter at the national or international level. Furthermore, the 1990s saw MaF disappeared and a new women's rights group, also called MaF, was founded at the beginning of the 2000 s. Fifth, there was strong and widespread resistance to the SVAW campaign even among the EC members. It was primarily related to the content of the campaign and not to its flagship role or its structure. At the same time, there was important opposition to the adoption of a policy on abortion from the membership.

\subsubsection{Comparison between the Swiss and the German Al sections}

Let me briefly recapitulate the findings from the two case studies on the basis of the five criteria measuring a section's success in integrating VAW into its work.

Figure 15 provides a comparison of the success of the Swiss and the German sections in integrating VAW into their work in the 2000 s on the basis of five criteria. Besides the leadership's commitment to the SVAW campaign (criteria 3), information for which is missing in the German case, the other criteria indicate that the Swiss section was more successful in integrating VAW into its work. In contrast to the German section, which continued to focus primarily on Al's traditional women's rights issues and did not address "domestic violence," the Swiss section adopted the thematic focus of the overall campaign and did emphasize "domestic violence" as a national human rights concern. Third, the Swiss section professionalized its work on VAW over the 
Figure 15: Comparison between the Swiss and the German AI sections of their success in integrating VAW into their section's work

\begin{tabular}{|c|c|c|}
\hline $\begin{array}{l}\text { Criteria success of integrating VAW } \\
\text { into the section's work }\end{array}$ & Swiss AI section & German AI section \\
\hline Adoption of the overall campaign ( 1 ) & $\begin{array}{l}\text { Adopted the thematic focus of the } \\
\text { general campaign and emphasized } \\
\text { "domestic violence" as a national } \\
\text { human rights concern for the first } \\
\text { time. }\end{array}$ & $\begin{array}{l}\text { Essentially focused on } \mathrm{Al}^{\prime} \mathrm{s} \\
\text { traditional women's rights issues } \\
\text { and did not address "domestic } \\
\text { violence" as a national human rights } \\
\text { issue. }\end{array}$ \\
\hline $\begin{array}{l}\text { Professionalization of the work } \\
\text { on issues of VAW (2) }\end{array}$ & $\begin{array}{l}\text { Created the position of campaign } \\
\text { coordinator; ensured its funding } \\
\text { beyond the SVAW campaign. }\end{array}$ & $\begin{array}{l}\text { No professionalization of the } \\
\text { section's work on VAW. }\end{array}$ \\
\hline $\begin{array}{l}\text { Commitment of the leadership } \\
\text { to the SVAW campaign (3) }\end{array}$ & $\begin{array}{l}\text { The section's leadership was } \\
\text { committed to the SVAW campaign. }\end{array}$ & - \\
\hline $\begin{array}{l}\text { Influence of the section's women's } \\
\text { network or group } \\
\text { (changes vis-a-vis the 1990s) (4) }\end{array}$ & $\begin{array}{l}\text { The women's network continued to } \\
\text { influence the section's work on } \\
\text { VAW in the frame of the SVAW } \\
\text { campaign implemented top-down. }\end{array}$ & Less important \\
\hline $\begin{array}{l}\text { Resistance to the SVAW campaign and } \\
\text { the adoption of the abortion policy (5) }\end{array}$ & $\begin{array}{l}\text { Certain skepticism towards the } \\
\text { campaign among officials, but the } \\
\text { SVAW campaign did not meet with } \\
\text { activists' and officials' resistance } \\
\text { against the SVAW campaign. } \\
\text { Opposition against the adoption of } \\
\text { an abortion policy was isolated. }\end{array}$ & $\begin{array}{l}\text { Strong and widespread resistance } \\
\text { against the SVAW campaign. } \\
\text { Important opposition against the } \\
\text { adoption of a policy on abortion. }\end{array}$ \\
\hline
\end{tabular}

Source: My own

course of the SVAW campaign. In contrast, just like in the 1990s, the personnel resources allocated to the thematic work on women's rights at the German secretariat never exceeded nine working hours per week. Fourth, while the Swiss section's women's network successfully pushed for further professionalizing its work on VAW through a sustainable approach to work on women's rights, the MaF was important for the implementation of the campaign but no longer tried to influence decision-making at the national or at the international level. Fifth, in contrast to the Swiss section, the German section witnessed strong and widespread resistance to the campaign Look \& Act: Preventing Violence against Women and harsh opposition to the adoption of a policy on abortion. These differences demonstrate that the Swiss section was more successful than the German section in integrating the issue of VAW into its work.

In order to account for this difference, it is worth looking at the central dissimilarities between the sections. Chapter 6.3.2 highlighted substantial differences in four domains: the power structure between the secretariat (professional structure) and the groups (activists). The latter have a relatively pow- 
erful position in the German section due to their role in the thematic work and their ability to participate in the decision-making both at the national and at the local level. In contrast, the Swiss professional structure seems to be more powerful than its membership, as thematic work is centralized and professionalized at the Secretariat. This particularity can serve as an explanation as to why the Swiss section professionalized its work on issues of VAW over the course of the SVAW campaign, while the German section continued to allocate only limited human resources to the work on women's rights. This conclusion also suggests that the "professionalization of the work on issues of VAW" criterion is not that useful when assessing a section's success in integrating VAW into its work. On the other hand, the relatively powerful position of the German section's membership may be one explanation for the resistance to the SVAW campaign and to the adoption of an abortion policy at the German section. It is worth assuming that German activists' comparatively huge opportunities to participate in the section's decision-making processes gave the policy opponents significantly more weight. Nevertheless, more member power does not necessarily translate into more resistance to these kinds of activities or policies. Instead, the reason for the resistance must be sought in the members' attitudes. The lack of data prevents us from knowing or measuring members' attitudes. However, there is some evidence that the German section's members are comparatively more conservative and traditionally closer to the Church. Further, in Germany, the Protestant Church (Evangelische Kirche in Deutschland) and the Catholic Church have had a long tradition of collaborating in the promotion of a common position on sexual and reproductive rights and abortion. Despite harboring differing views on abortion law, they have stood together for protecting life. ${ }^{355}$ Consequently, it is worth assuming that the German section's closeness to the Church explains its comparatively huge opposition to the campaign and its failure in integrating issues of VAW into its overall work. At the same time, the differences between the Swiss and the German sections might also come down to the fact that the share of women in the Swiss EC was higher than in the German EC over the whole period. While it is impossible to demonstrate a clear correlation, given the previous research on the relationship between the absence of women in leadership positions within organizations and the gender bias in the mainstreaming understanding of human rights, it is worth assuming that a link did exist. 
Sixth, it is also possible that the difference between the Swiss and the German sections had to do with the relationship between the section and the headquarters. In fact, the data indicate that the Swiss section was open to mandate changes and a rather assimilated member of the overall AI network. This is in contrast to its neighbor, which has been described as rather critical to mandate changes and whose relationship with the IS has been characterized as periodically conflictual. Thus, the Germans' refusal to address "domestic violence" as a national human rights issues, while continuing to work on traditional women's rights issues, such as female human rights defenders and FGM, under the SVAW campaign, can be interpreted more as a sign of a generally critical stance to propositions coming from the headquarters than as a sign of refusal to work on issues of women's rights.

Ultimately, it is difficult to definitively conclude why the Swiss section was more successful than the German section in integrating issues of VAW into its work through the SVAW campaign. A definite answer certainly needs a database of interviews with a greater number of activists and officials. Furthermore, taking the respective national political and legislative contexts into account would provide a deeper - and better - understanding of this difference. In the Swiss case, the successful process of designing and passing a law that made domestic violence a crime persecuted ex officio ${ }^{356}$ in the Swiss Parliament between 1996 and 2003 - which also contributed to sensitizing the Swiss public in general - certainly could have helped the campaign to unlaesh. However, a similar legislative process took place in Germany during the same period. In fact, the Federal Government adopted the first Action Plan to combat violence against women in 1999. The Protection against Violence Act (Gewaltschutzgesetz) was an essential component of this plan and came into effect in 2002, bringing the issue of domestic violence out of its niche and making it claim its place in the legal-political and juridical discussion. ${ }^{357}$ Thus, a legislation process that mirrored the international debate on the recognition of VAW as a violation of human rights, and which could be used to explain the difference between the two sections, took place in both countries. Nevertheless, the present study does not define if and how these

356 Frauen Macht Geschichte. Frauenpolitik und Gleichstellung in der Schweiz 2001-2017. Bern 2017. Herausgeberin: Eidgenössische Kommission für Frauenfragen EKF.

357 Berliner Initiative gegen Cewalt an Frauen BIC e.V. 10 Jahre Cewaltschutzgesetz, 1. Auflage 2012. 
national legal and political developments affected public opinion and influenced the implementation of AI's campaign in Switzerland and Germany. Indeed, more research and a broader focus are needed to better understand these relationships.

Given AI's basic nature of a membership organization based on democratic principles, which gives members the possibility to define the organization's working focus, the attitude of a section's membership towards the SVAW campaign or the adoption of an abortion policy is paramount to the section's actions. In turn, this suggests that the German section's generally rather conservative membership, visible in its relative closeness to the Church, combined with activists' comparatively huge opportunities to participate in the section's decision-making processes to further amplify opposition to the SVAW campaign and contribute to the section's failure to integrate issues of VAW into its overall work.

\subsection{Intermediate conclusions}

Before continuing with the discussion of the empirical findings, it is worth summing up the insights into the post-mandate period that this chapter has provided. In the 2000s, AI adopted a first policy on sexual and reproductive rights and abortion, framing these rights as civil and political rights as well as economic, social, and cultural rights. In so doing, it recognized them as essential "to the realization of every individual's human rights." ${ }^{358}$ Additionally, the organization made the principle of gender equality part of its policy at the end of the 2000s. Chapter 8 has illustrated how the content of AI's work on VAW evolved with the launch of the SVAW campaign, when the organization emphasized the issue of domestic violence for the first time and engaged in a comprehensive internal change. With the latter, AI members and staff embraced the campaign's underlining principle of gender equality and integrated the principle of "Women's Rights are Human Rights" into their work and activism.

Further, my focus on the origin of the relevant ICM decisions and on the implementation of the SVAW campaign has revealed a top-down process of

358 Amnesty International, International Secretariat: Statement Summarizing Al's current policy on Sexual and Reproductive Rights, 12.10.2006, p.2. 
integrating VAW into AI's work in the post-mandate period. The organization's leadership initiated the majority of the relevant ICM decisions and established a campaign machinery at the IS for the effective implementation of the SVAW campaign.

Nevertheless, AI did not succeed in integrating VAW into its work. The analysis of the role of the women's rights activists and officials and the reaction to the SVAW campaign and the adoption of an abortion policy indicates that this failure has two principal reasons. First, with the SVAW campaign being implemented from the top down, the female activists and officials who had initiated AI's work on VAW in the 1990s lost their influence on the organization's work on the topic. Second, activists and officials at the international and the national levels opposed the SVAW campaign and members resisted the adoption of a policy on abortion.

However, the focus on the national level has showed that there were considerable differences in the extent to which the Swiss and the German sections managed to integrate the issue of VAW into their work in the 2000 s. Whereas the Swiss section at least partially succeeded in integrating the issue of VAW into its work, the German section did not do so. I argue that the German section members' relative closeness to the Church and their comparatively powerful position help explain this difference between the two sections. 